Review

\title{
Chemical-Looping Combustion and Gasification of Coals and Oxygen Carrier Development: A Brief Review
}

\author{
Ping Wang ${ }^{1, *}$, Nicholas Means ${ }^{2}$, Dushyant Shekhawat ${ }^{3}$, David Berry ${ }^{3}$ and Mehrdad Massoudi ${ }^{1}$ \\ 1 Department of Energy, National Energy Technology Laboratory, 626 Cochrans Mill Road, \\ Pittsburgh, PA 15236, USA; E-Mail: mehrdad.massouri@netl.doe.gov \\ 2 AECOM, 626 Cochrans Mill Road, PO Box 10940, Pittsburgh, PA 15236, USA; \\ E-Mail: Nicholas.means@netl.doe.gov \\ 3 Department of Energy, National Energy Technology Laboratory, 3610 Collins Ferry Road, \\ Morgantown, WV 26507, USA; E-Mails: dushyant.shekhawat@netl.doe.gov (D.S.); \\ david.berry@netl.doe.gov (D.B.) \\ * Author to whom correspondence should be addressed; E-Mail: ping.wang@netl.doe.gov; \\ Tel.: +1-412-386-7539; Fax: +1-412-386-5870.
}

Academic Editor: Vasily Novozhilov

Received: 24 July 2015 / Accepted: 16 September 2015 / Published: 24 September 2015

\begin{abstract}
Chemical-looping technology is one of the promising $\mathrm{CO}_{2}$ capture technologies. It generates a $\mathrm{CO}_{2}$ enriched flue gas, which will greatly benefit $\mathrm{CO}_{2}$ capture, utilization or sequestration. Both chemical-looping combustion (CLC) and chemical-looping gasification (CLG) have the potential to be used to generate power, chemicals, and liquid fuels. Chemical-looping is an oxygen transporting process using oxygen carriers. Recently, attention has focused on solid fuels such as coal. Coal chemical-looping reactions are more complicated than gaseous fuels due to coal properties (like mineral matter) and the complex reaction pathways involving solid fuels. The mineral matter/ash and sulfur in coal may affect the activity of oxygen carriers. Oxygen carriers are the key issue in chemical-looping processes. Thermogravimetric analysis (TGA) has been widely used for the development of oxygen carriers (e.g., oxide reactivity). Two proposed processes for the CLC of solid fuels are in-situ Gasification Chemical-Looping Combustion (iG-CLC) and Chemical-Looping with Oxygen Uncoupling (CLOU). The objectives of this review are to discuss various chemical-looping processes with coal, summarize TGA applications in oxygen carrier development, and outline the major challenges associated with coal chemical-looping in iG-CLC and CLOU.
\end{abstract}


Keywords: chemical-looping combustion; chemical-looping gasification; coal; solid fuels; oxygen-carriers; thermogravimetric analysis (TGA)

\section{Introduction}

World energy demand has changed dynamically and is projected 37\% higher in 2040 due to regional growth in China, India, Southeast Asia, the Middle East, and parts of Africa and Latin America [1]. Coal, low-carbon sources (nuclear and renewables), oil, and natural gas will almost equally supply energy demands by 2040 because coal is abundant and its supply is relatively secure [1]. The future use of coal faces challenges such as high efficiency, low pollution, and reduced $\mathrm{CO}_{2}$ emission. A major driving force for the development of chemical-looping technology in coal utilization is to control carbon dioxide $\left(\mathrm{CO}_{2}\right)$ emissions. $\mathrm{CO}_{2}$ is a primary greenhouse gas and is widely believed to be responsible for climate change. Chemical-looping is one of the promising $\mathrm{CO}_{2}$ capture technologies along with pre-combustion, post-combustion, and oxy-combustion. It generates a $\mathrm{CO}_{2}$-enriched flue gas, which will greatly benefit $\mathrm{CO}_{2}$ capture and sequestration. It also has the potential to significantly reduce the energy penalty of $\mathrm{CO}_{2}$ capture from power plants. The techno-economic evaluation by Babcock and Wilcox Power Generation Group, Inc. (B and W PGG), in collaboration with Ohio State University (OSU), shows that the 550 MWe commercial scale coal direct chemical-looping (CDCL) power plant, using an iron-based oxygen carrier, captures $96.5 \%$ of the $\mathrm{CO}_{2}$ with a $28.8 \%$ increase in the cost of electricity [2].

Proposed chemical-looping processes include oxygen transport using oxygen carriers $\left(\mathrm{Me}_{\mathrm{x}} \mathrm{O}_{\mathrm{y}-1} / \mathrm{Me}_{\mathrm{x}} \mathrm{O}_{\mathrm{y}}\right.$ or $\left.\mathrm{MeS} / \mathrm{MeSO}_{4}\right)$ and $\mathrm{CO}_{2}$ transport using $\mathrm{CO}_{2}$ carriers $\left(\mathrm{MeO} / \mathrm{MeCO}_{3}\right)$ [3-5]. Oxygen transporting processes are common in chemical-lopping and are the focus of this review. Chemical-looping is a cycling process that uses an oxygen carrier to transfer oxygen from the air to the fuel via oxidation-reduction reactions. Chemical-looping can be used to generate electricity in fuel combustion (chemical-looping combustion CLC), hydrogen in fuel gasification (chemical-looping gasification CLG), chemicals, and liquid fuels. Figure 1 shows a typical CLC process that consists of a fuel reactor and an air reactor [4]. In the fuel reactor, a solid oxygen-carrier is reduced, thus providing oxygen for the fuel conversion. To close the loop, the reduced oxygen-carrier is re-oxidized in the air reactor before beginning a new cycle. The reactions of the fuel and oxygen carrier in the fuel and air reactors are shown in Reactions 1 and 2, respectively.

$$
\begin{gathered}
\text { Fuel }+\mathrm{nMe}_{\mathrm{x}} \mathrm{O}_{\mathrm{y}} \rightarrow \mathrm{nMe}_{\mathrm{x}} \mathrm{O}_{\mathrm{y}-1}+\mathrm{H}_{2} \mathrm{O}+\mathrm{CO}_{2} \\
\mathrm{Me}_{\mathrm{x}} \mathrm{O}_{\mathrm{y}-1}+1 / 2 \mathrm{O}_{2} \rightarrow \mathrm{Me}_{\mathrm{x}} \mathrm{O}_{\mathrm{y}}
\end{gathered}
$$

In these reactions, $\mathrm{Me}_{\mathrm{x}} \mathrm{O}_{\mathrm{y}}$ is the oxidized oxygen carrier and $\mathrm{Me}_{\mathrm{x}} \mathrm{O}_{\mathrm{y}-1}$ is the reduced oxygen carrier [6]. The gases generated from the fuel reactor are $\mathrm{H}_{2} \mathrm{O}$ and $\mathrm{CO}_{2}$. The $\mathrm{CO}_{2}$ can be recovered and sequestrated by condensing the $\mathrm{H}_{2} \mathrm{O}$. The gases from the air reactor are $\mathrm{N}_{2}$ with unused $\mathrm{O}_{2}$. In the overall reaction, obtained by combining Reactions 1 and 2, the fuel is combusted and $\mathrm{CO}_{2}$ is separated from $\mathrm{N}_{2}$ in the air [7]. Fuels in chemical-looping may be gaseous fuels (natural gas, refinery gas, syngas, etc.) or solid fuels (coal, petroleum coke, and biomass). Chemical-looping combustion with gaseous fuels has been mainly studied and developed in recent years and was reviewed by Adanez et al. [3] and Hossain and de Lasa [8]. More recently, CLC research has focused on solid fuels because of rich solid fuel resources [9-22]. 


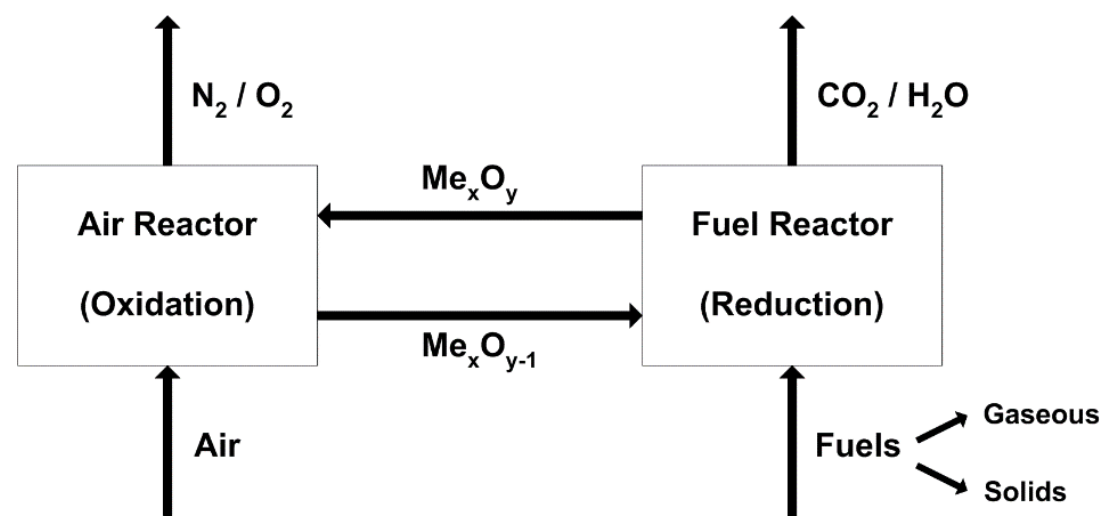

Figure 1. Schematic of the chemical-looping combustion process, which is a cycling process that consists of a fuel reactor and an air reactor [4].

Heat generated from CLC can be used to generate power. Depending on the oxygen carrier and fuel, the reduction reaction (Reaction 1) can be endothermic (common) or exothermic. The oxidation reaction (Reaction 2) is always exothermic. If Reaction 1 is endothermic, the heat required in the fuel reactor can be provided by the solid oxygen carrier that is cycled between the fluidized beds [7]. In a proposed integrated CLC-based power plant, the power generation steps are: (1) the outlet gas from the air reactor drives the gas turbine or air turbine; (2) the flue gas from the fuel reactor drives the $\mathrm{CO}_{2}$ turbine; and (3) the exhaust from the air turbine passes through a heater to generate low pressure steam which is used in the steam turbine to generate extra power [8]. To maximize the turbine efficiency, high temperatures in both the air and fuel reactors are ideal. As a result, the oxygen carrier operating at high temperature is preferred.

Coal chemical-looping processes are more complicated than gaseous fuels due to the properties of coal. Coal is a heterogeneous material and consists of organic matter (carbon, hydrogen, oxygen, nitrogen, and sulfur) and mineral matter (ash, subsequent to combustion and gasification) [23-25]. Effectively removing ash from the fuel reactor is challenging and inevitably results in losses of the oxygen carrier $[6,13]$. Due to this, low cost oxygen carriers are preferred. Additionally, the ash may impact the oxygen carrier by reducing the carrier lifetime [9]. Sulfur can cause losses in the reactivity of the oxygen carrier [26]. For solid fuel chemical-looping, syngas chemical-looping combustion/gasification, and direct solid fuel chemical-looping combustion/gasification are two major proposed technical approaches. In syngas chemical-looping, coal is first gasified to syngas (mainly $\mathrm{CO}$ and $\mathrm{H}_{2}$ ). Then, syngas reacts with the oxygen carrier as a gaseous fuel to combust or convert to $\mathrm{H}_{2}$ (syngas reforming). Direct chemical-looping feeds coal into the fuel reactor. Reactions of coal pyrolysis, volatile oxidation, and char oxidation take place in the same reactor. To achieve high $\mathrm{CO}_{2}$ capture, the key targets for the fuel reactor are: (1) high solid fuel conversion (i.e., no unconverted char in the solid products) and (2) high gas conversion (i.e., no unconverted gases such as $\mathrm{CO}, \mathrm{H}_{2}$, and $\mathrm{CH}_{4}$ in the flue gas) [13]. In general, high reactivity of the oxygen carrier and fuel is required. The complete conversion of volatiles and char with high reaction rates are a few of the major challenges associated with this process.

Oxygen carriers are the key to the development of chemical-looping technologies. Two types of oxygen carriers proposed in the literature are synthetic materials and natural minerals. Synthetic oxygen carriers are generally composed of single metal oxides, combined or mixed metal oxides (usually first row transition metal oxides of $\mathrm{Ni}, \mathrm{Fe}, \mathrm{Cu}, \mathrm{Mn}, \mathrm{Co}$, etc. $)$ and an inert support $\left(\mathrm{Al}_{2} \mathrm{O}_{3}, \mathrm{SiO}_{2}, \mathrm{MgAl}_{2} \mathrm{O}_{4}\right.$, 
$\mathrm{TiO}_{2}, \mathrm{ZrO}_{2}$, etc.) [3]. The low cost natural minerals are iron ore, ilmenite, manganese ore, and waste materials coming from the steel industry and alumina production (bauxite waste, combustion ash, etc.) [3,15,16,27-34]. Synthetic oxygen carriers are commonly researched. The motivation for developing natural minerals and waste residues is the low cost. In coal chemical-looping, ash can be difficult to separate from the oxygen carrier. As a result, it is easy to discard ash and oxygen carrier together. In general, natural minerals usually have lower reactivity than synthetic oxygen carriers. Research on improving natural mineral reactivity with the addition of metal oxides or alkali and alkaline metals $(\mathrm{K}+, \mathrm{Na}+$, or $\mathrm{Ca}+)$ has been reported [35-38].

Two coal direct CLC processes are in situ Gasification Chemical-Looping Combustion (iG-CLC) [6,18] and Chemical-Looping with Oxygen Uncoupling (CLOU) [14]. In iG-CLC, the fuel gasification and the syngas CLC take place in a same fuel reactor. Iron-based oxygen carriers have often been used in iG-CLC [7,39-41]. In the CLOU process, gaseous oxygen released from the oxygen carrier combusts the fuel. The fuel conversion rate in CLOU is faster than in iG-CLC because CLOU avoids the slow gasification of fuel with $\mathrm{H}_{2} \mathrm{O}$ and/or $\mathrm{CO}_{2}$ [14]. The major metal oxide systems identified for CLOU are $\mathrm{CuO} / \mathrm{Cu}_{2} \mathrm{O}, \mathrm{Mn}_{2} \mathrm{O}_{3} / \mathrm{Mn}_{3} \mathrm{O}_{4}$, and $\mathrm{Co}_{3} \mathrm{O}_{4} / \mathrm{CoO}$ [14]. $\mathrm{CuO}$ has been tested in both iG-CLC and CLOU. In $\mathrm{CLOU}, \mathrm{CuO}$ is reduced to $\mathrm{Cu}_{2} \mathrm{O}$ at higher temperature $\left(850-1000{ }^{\circ} \mathrm{C}\right) . \mathrm{CuO}$ releases oxygen in this temperature range and the melting temperature of $\mathrm{Cu}_{2} \mathrm{O}$ is $1235^{\circ} \mathrm{C}$. $\mathrm{CuO}$ is reduced to $\mathrm{Cu}$ in iG-CLC. Typically, low temperature $\left(600^{\circ} \mathrm{C}\right)$ and/or low $\mathrm{CuO}$ content (less than $\left.20 \mathrm{wt} . \%\right)$ are used to avoid agglomeration due to the low melting temperature of $\mathrm{Cu}\left(1085{ }^{\circ} \mathrm{C}\right)[10,42]$. CLOU is especially suitable for solid fuel although $\mathrm{CuO} / \mathrm{Cu}_{2} \mathrm{O}$ systems have lower oxygen transport capacities compared to $\mathrm{CuO} / \mathrm{Cu}$ systems.

Thermogravimetric analysis (TGA) has been used in every step of the development of solid fuel chemical-looping. First, research focused on identifying suitable oxygen carriers. TGA is commonly used along with fixed bed and bubbling fluidized bed reactors. To develop $\mathrm{Cu}$-based oxygen carriers for CLOU, Instituto de Carboquímica (ICB-CSIC) tested 25 different carriers prepared using various methods, $\mathrm{CuO}$ content and support materials [43-45]. TGA was used to study the reactivity of carriers in reduction and oxidation. Mechanical stability and fluidization properties of the carriers were tested in a batch fluidized bed. Next, efforts focused on scale-up and validation of oxygen carriers, reactor design, engineering, construction, and operation. CLC processes typically use two interconnected fluidized beds in both batch and continuous operation. TGA is also used to conduct comparison studies and provide helpful kinetic information [46].

Lab-scale reactor testing has focused on identification of suitable oxygen carrier materials with favorable reaction kinetics, deactivation, and stability. In addition to monometallic oxides, combined or mixed metal oxides have been investigated [13]. Mn combined with $\mathrm{Fe}, \mathrm{Ca}, \mathrm{Mg}, \mathrm{Ni}$, and $\mathrm{Si}$ form new compounds with partial CLOU properties [47-49]. For coal iG-CLC, low cost oxygen carriers such as ilmenite $[6,39,50,51]$, iron ore [26,38,52], manganese ore [9,53], and industrial waste [28] have been tested in two interconnected continuous fluidized bed (CFB) $0.5-100 \mathrm{~kW}$ reactors. Among the tested oxygen carriers, ilmenite was often studied because it is cheap, has high reactivity with syngas, and has good fluidization behavior [13]. For coal CLOU, a Cu-based carrier of $60 \% \mathrm{CuO}$ with $\mathrm{MgAl}_{2} \mathrm{O}_{4}$ as a support (Cu60MgAL) was tested in a $1.5 \mathrm{KW} \mathrm{CFB} \mathrm{[43].} \mathrm{All} \mathrm{tests} \mathrm{demonstrated} \mathrm{the} \mathrm{proof} \mathrm{of} \mathrm{the} \mathrm{concept}$ of coal CLC. 
The objectives of this review are: (1) to give a brief introduction to different solid fuel chemical-looping processes; (2) to summarize experimental lab scale studies on oxygen carrier development for solid fuel chemical-looping processes, and (3) to discuss challenges in coal chemical-looping combustion processes, including iG-CLC and CLOU.

\section{Major Proposed Solid Fuel Chemical-Looping Combustion (CLC) and Gasification (CLG)}

\subsection{Major Proposed Solid Fuel Chemical-Looping Combustion Processes}

Syngas-CLC and direct solid fuel CLC are two major types of chemical-looping processes [3]. In syngas CLC, solid fuel (e.g., coal) is first pyrolyzed to char and volatile gas then gasified to syngas (mainly $\mathrm{CO}$ and $\mathrm{H}_{2}$ ). The syngas reacts with the oxygen carrier, similar to gas fuels CLC (Figure 2a) $[13,54]$. The heat required for the endothermic gasification reaction can come from the partial oxygen combustion of coal or the CLC system. In the latter case, a gasifier is placed inside the air reactor. This method has the difficulty of heat transfer between the two reactors. In direct solid fuel CLC, coal is directly fed to the fuel reactor in a CLC process. Two of these direct processes are in situ Gasification Chemical-Looping Combustion (iG-CLC) (Figure 2b) [6,18] and Chemical-Looping with Oxygen Uncoupling (CLOU) (Figure 2c) [14]. For syngas CLC, pure oxygen needed for gasifying the coal is separated from air and consumes energy. Furthermore, the requirement of an additional gasifier dramatically increases the capital cost of the syngas CLC process [10]. Syngas chemical-looping combustion reactors have been widely researched, so this review focuses on direct solid fuel CLC.

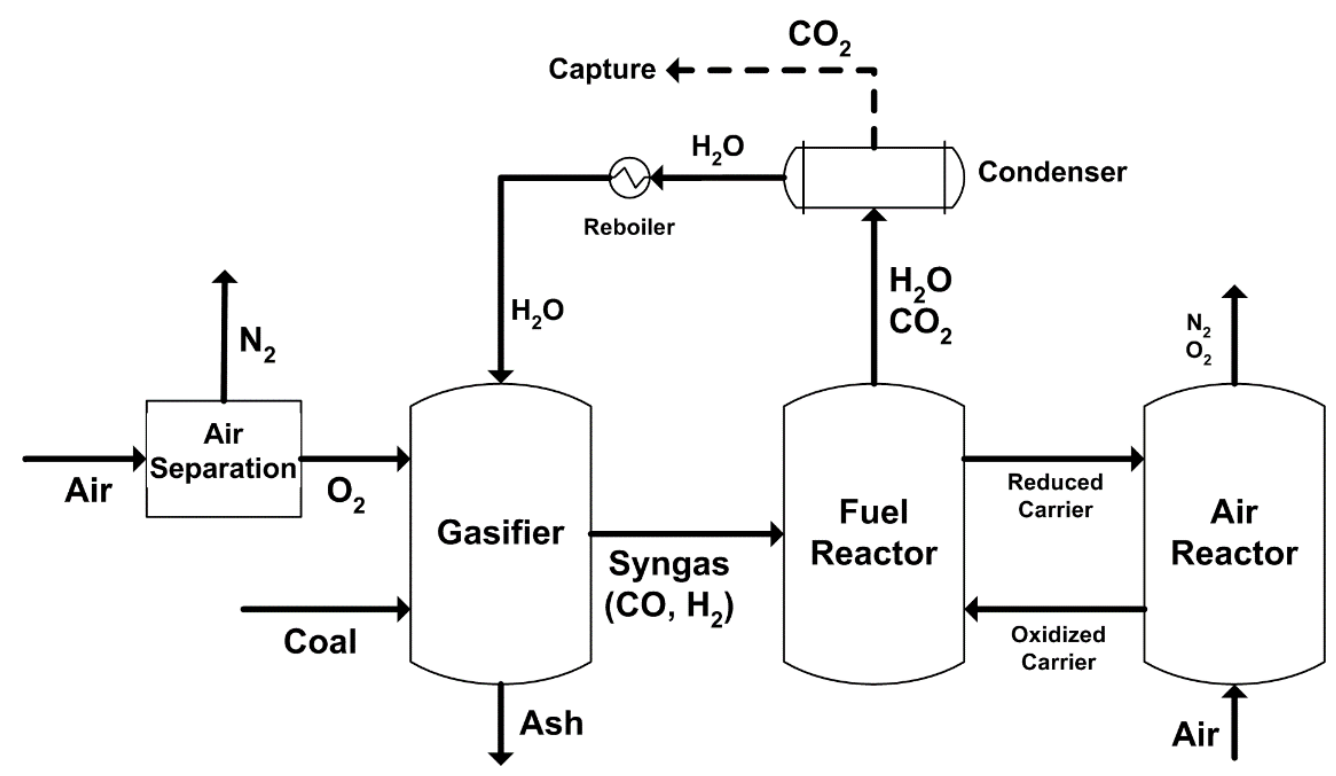

(a)

Figure 2. Cont. 


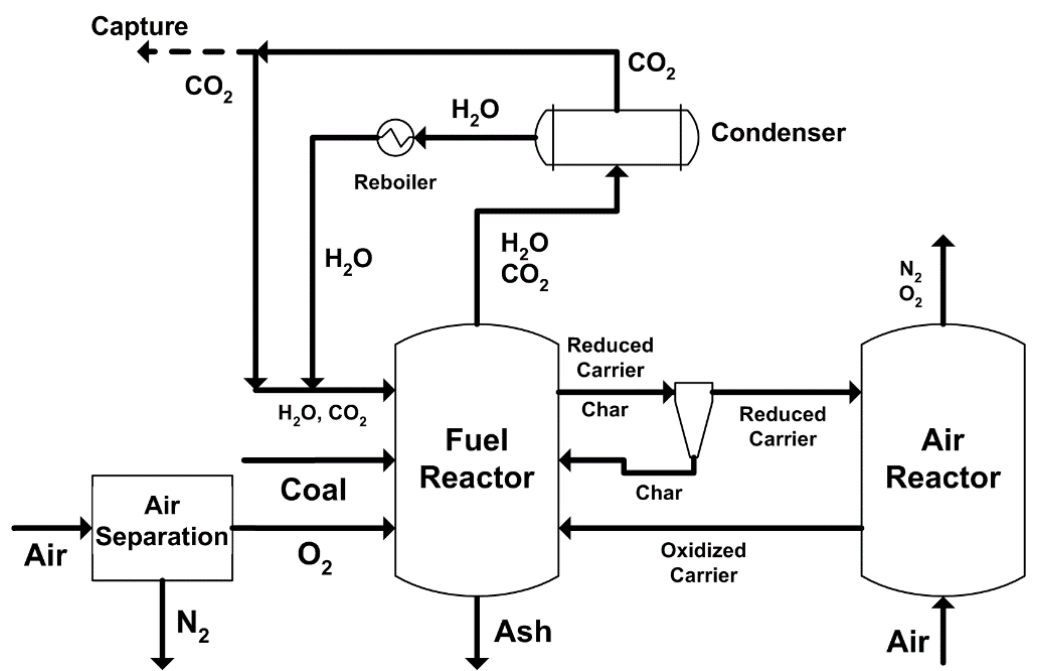

(b)

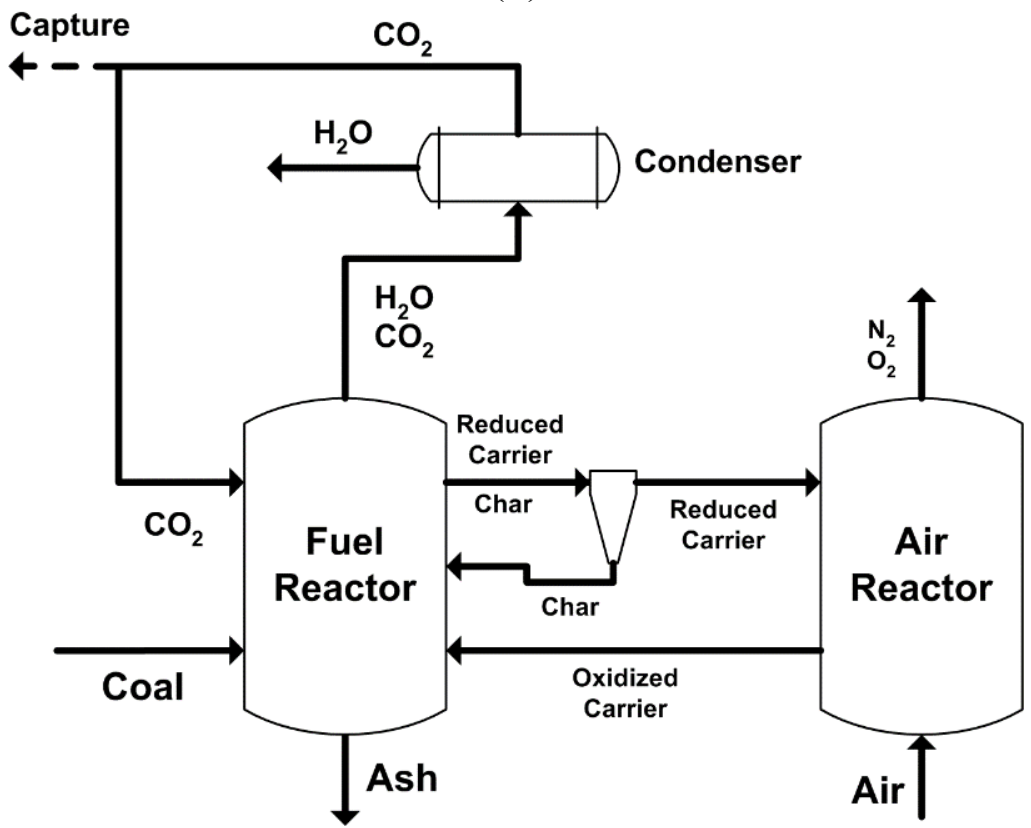

(c)

Figure 2. Major reaction processes of solid fuels in chemical-looping combustion (CLC): (a) Syngas-CLC; (b) in situ gasification CLC (iG-CLC); and (c) CLC with oxygen uncoupling (CLOU) [3].

In the iG-CLC process (Figure 2b), coal is physically mixed with the oxygen-carrier in the fuel reactor. Prior to reaction with the oxygen-carrier, coal is devolatilized generating volatiles and char (Reaction 3) [55,56]. The char is gasified in situ by $\mathrm{H}_{2} \mathrm{O}$ and/or $\mathrm{CO}_{2}$, supplied as a fluidizing agent, to produce syngas $\left(\mathrm{H}_{2}\right.$ and $\mathrm{CO}$ ) (Reactions $\left.4-5\right)$. In the fuel reactor, the carrier reacts with the volatiles from pyrolysis and the syngas from char gasification (Reaction 1). In this process, char gasification is the rate limiting step because gasification is slower than the syngas reaction with oxygen carriers [12]. Another important factor is properties of solid fuels (such as volatile content), which affects selection of gasifying agent. The use of $\mathrm{CO}_{2}$ has been proposed for highly reactive solid fuels, such as low-rank coals or biomass [12]. For high rank coals, steam is needed because of the slow gasification rate with $\mathrm{CO}_{2}$. 


$$
\begin{gathered}
\text { Coal } \rightarrow \text { volatiles }+ \text { char }(\mathrm{C}) \\
\mathrm{C}_{(\mathrm{s})}+\mathrm{H}_{2} \mathrm{O}_{(\mathrm{g})} \rightarrow \mathrm{CO}_{(\mathrm{g})}+\mathrm{H}_{2(\mathrm{~g})} \\
\Delta \mathrm{H}^{\circ}{ }_{298}=131.1 \mathrm{~kJ} / \mathrm{mol} \\
\mathrm{C}_{(\mathrm{s})}+\mathrm{CO}_{2(\mathrm{~g})} \rightarrow 2 \mathrm{CO}_{(\mathrm{g})} \\
\Delta \mathrm{H}^{\circ}{ }_{298}=172.5 \mathrm{~kJ} / \mathrm{mol}
\end{gathered}
$$

In the CLOU process (Figure 2c), the oxygen-carrier in the fuel-reactor releases gaseous oxygen (Reaction 6) resulting in solid fuel combustion. Like conventional combustion, coal is devolatilized to generate volatiles and char, then the volatiles and char are combusted with gaseous oxygen (Reactions 3 , 7-8). Compared to the iG-CLC process, CLOU avoids the slow char gasification step. CLOU is considered a promising technology to burn solid fuels with $\mathrm{CO}_{2}$ capture [14]. Oxygen release from oxygen carriers, coal pyrolysis, and char/syngas combustion all take place in the fuel reactor (Reactions 3, 6-8) [46]. Three of the major metal oxide systems identified for $\mathrm{CLOU}$ are $\mathrm{CuO} / \mathrm{Cu}_{2} \mathrm{O}, \mathrm{Mn}_{2} \mathrm{O}_{3} / \mathrm{Mn}_{3} \mathrm{O}_{4}$, and $\mathrm{Co}_{3} \mathrm{O}_{4} / \mathrm{CoO}$ [14]. For these three metal oxides, oxygen uncoupling reactions (Reactions 9-11) are endothermic. The overall reaction of carbon in the fuel reactor with copper or manganese oxide is exothermic (Reactions 12-13) and the reaction with cobalt oxide is endothermic (Reaction 14) [43]. To date, great attention has been given to $\mathrm{Cu}$-based and $\mathrm{Mn}$-based materials mixed with $\mathrm{Ca}, \mathrm{Mg}, \mathrm{Cu}, \mathrm{Ni}$, Fe or Si [47,48,57-60].

$$
\begin{gathered}
2 \mathrm{Me}_{\mathrm{x}} \mathrm{O}_{\mathrm{y}} \leftrightarrow 2 \mathrm{Me}_{\mathrm{x}} \mathrm{O}_{\mathrm{y}-1}+\mathrm{O}_{2(\mathrm{~g})} \\
\text { volatiles }+\mathrm{O}_{2(\mathrm{~g})} \rightarrow \mathrm{CO}_{2(\mathrm{~g})}+\mathrm{H}_{2} \mathrm{O}_{(\mathrm{g})} \\
\text { char }(\mathrm{C})+\mathrm{O}_{2(\mathrm{~g})} \rightarrow \mathrm{CO}_{2(\mathrm{~g})} \\
4 \mathrm{CuO} \leftrightarrow 2 \mathrm{Cu}_{2} \mathrm{O}+\mathrm{O}_{2(\mathrm{~g})} \\
\Delta \mathrm{H}^{\circ}{ }_{900}=262.1 \mathrm{~kJ} / \mathrm{mol} \mathrm{O}_{2} \\
6 \mathrm{Mn}_{2} \mathrm{O}_{3} \leftrightarrow 4 \mathrm{Mn}_{3} \mathrm{O}_{4}+\mathrm{O}_{2(\mathrm{~g})} \\
\Delta \mathrm{H}^{\circ}{ }_{900}=193.1 \mathrm{~kJ} / \mathrm{mol} \mathrm{O}_{2} \\
2 \mathrm{Co}_{3} \mathrm{O}_{4} \leftrightarrow 6 \mathrm{CoO}+\mathrm{O}_{2(\mathrm{~g})} \\
\Delta \mathrm{H}^{\circ}{ }_{900}=406.7 \mathrm{~kJ} / \mathrm{mol} \mathrm{O}_{2} \\
4 \mathrm{CuO}+\mathrm{C} \leftrightarrow 2 \mathrm{Cu} \mathrm{O}+\mathrm{O}_{2(\mathrm{~g})} \\
\Delta \mathrm{H}^{\circ} 900=-132.9 \mathrm{~kJ} / \mathrm{mol} \mathrm{O}_{2} \\
6 \mathrm{Mn}_{2} \mathrm{O}_{3}+\mathrm{C} \leftrightarrow 4 \mathrm{Mn} 3 \mathrm{O}_{4}+\mathrm{O}_{2(\mathrm{~g})} \\
\Delta \mathrm{H}^{\circ}{ }_{900}=-201.9 \mathrm{~kJ} / \mathrm{mol} \mathrm{O}_{2} \\
2 \mathrm{Co}_{3} \mathrm{O}_{4}+\mathrm{C} \leftrightarrow 6 \mathrm{CoO}+\mathrm{O}_{2(\mathrm{~g})} \\
\Delta \mathrm{H}_{900}^{\circ}=11.7 \mathrm{~kJ} / \mathrm{mol} \mathrm{O}_{2}
\end{gathered}
$$

\subsection{Major Proposed Solid Fuel Chemical-Looping Gasification Processes}

Syngas chemical-looping (SCL) and direct chemical-looping (DCL) are two methods for solid fuel chemical-looping gasification to generate hydrogen, power, and liquid fuels [61]. In SCL, syngas from coal gasification is converted to $\mathrm{H}_{2}$ by an iron-based oxygen carrier (Figure 3a) or a calcium-based 
carrier (Figure 3b) [61,62]. Chemical looping is used to enhance $\mathrm{H}_{2}$ and $\mathrm{CO}_{2}$ production as part of a conventional gasification [63]. In the iron-based process, the syngas is converted into $\mathrm{CO}_{2}$ and $\mathrm{H}_{2} \mathrm{O}$ and the iron oxide $\left(\mathrm{Fe}_{2} \mathrm{O}_{3}\right)$ is reduced to a mixture of $\mathrm{Fe}$ and $\mathrm{FeO}$ at $750-900{ }^{\circ} \mathrm{C}$ and 30 atm in the fuel reactor (Reactions 15-18). In the hydrogen reactor, the reduced oxide reacts with steam to generate $\mathrm{H}_{2}$ at 500-750 ${ }^{\circ} \mathrm{C}$ and $30 \mathrm{~atm}$ (Reaction $19-20$ ). The $\mathrm{Fe}_{3} \mathrm{O}_{4}$ generated from the hydrogen reactor is regenerated to $\mathrm{Fe}_{2} \mathrm{O}_{3}$ through air combustion (Reaction 21). In the calcium looping process (CLP), the syngas is converted to $\mathrm{H}_{2}$ in a carbonation reactor using $\mathrm{CaO}$ and water gas shift (Reaction 22) at 550-650 ${ }^{\circ} \mathrm{C}$ and $20-30 \mathrm{~atm}$. At same time, removal of syngas contaminants (sulfur and $\mathrm{HCl}$ ), $\mathrm{CO}_{2}$ capture, and reforming (Reactions 23-26) take place. The spent calcium sorbent is regenerated in a calciner, while $\mathrm{CO}_{2}$ is produced at $800-1000{ }^{\circ} \mathrm{C}$ and atmospheric pressure (Reaction 27).

$$
\begin{gathered}
\mathrm{Fe}_{2} \mathrm{O}_{3}+\mathrm{CO}_{(\mathrm{g})} \rightarrow 2 \mathrm{FeO}+\mathrm{CO}_{2(\mathrm{~g})} \\
\mathrm{FeO}+\mathrm{CO}_{(\mathrm{g})} \rightarrow \mathrm{Fe}+\mathrm{CO}_{2}(\mathrm{~g}) \\
\mathrm{Fe}_{2} \mathrm{O}_{3}+\mathrm{H}_{2}(\mathrm{~g}) \rightarrow 2 \mathrm{FeO}+\mathrm{H}_{2} \mathrm{O}_{(\mathrm{g})} \\
\mathrm{FeO}+\mathrm{H}_{2(\mathrm{~g})} \rightarrow \mathrm{Fe}+\mathrm{H}_{2} \mathrm{O}_{(\mathrm{g})} \\
\mathrm{Fe}+\mathrm{H}_{2} \mathrm{O}_{(\mathrm{g})} \rightarrow \mathrm{FeO}+\mathrm{H}_{2}(\mathrm{~g}) \\
3 \mathrm{FeO}+\mathrm{H}_{2} \mathrm{O}_{(\mathrm{g})} \rightarrow \mathrm{Fe}_{3} \mathrm{O}_{4}+\mathrm{H}_{2(\mathrm{~g})} \\
4 \mathrm{Fe}_{3} \mathrm{O}_{4}+\mathrm{O}_{2(\mathrm{~g})} \rightarrow 6 \mathrm{Fe}_{2} \mathrm{O}_{3} \\
\mathrm{CO}_{(\mathrm{g})}+\mathrm{H}_{2} \mathrm{O}(\mathrm{g}) \leftrightarrow \mathrm{CO}_{2}(\mathrm{~g})+\mathrm{H}_{2(\mathrm{~g})} \\
\mathrm{CaO}+\mathrm{CO}_{2}(\mathrm{~g}) \rightarrow \mathrm{CaCO}_{3} \\
\mathrm{CaO}+\mathrm{COS}_{(\mathrm{g})} \rightarrow \mathrm{CaS}+\mathrm{CO}_{2(\mathrm{~g})} \\
\mathrm{CaO}+\mathrm{H}_{2} \mathrm{~S}_{(\mathrm{g})} \rightarrow \mathrm{CaS}+\mathrm{H}_{2} \mathrm{O}_{(\mathrm{g})} \\
\mathrm{CaO}+2 \mathrm{HCl}_{(\mathrm{g})} \rightarrow \mathrm{CaCl}_{2}+\mathrm{H}_{2} \mathrm{O}_{(\mathrm{g})} \\
\mathrm{CaCO} \rightarrow \mathrm{CaO}_{3}+\mathrm{CO}_{2(\mathrm{~g})}
\end{gathered}
$$

In iron-based DCL (Figure 3c), coal is converted into $\mathrm{CO}_{2}$ and $\mathrm{H}_{2} \mathrm{O}$, while iron oxide $\left(\mathrm{Fe}_{2} \mathrm{O}_{3}\right)$ is reduced to a mixture of $\mathrm{Fe}$ and $\mathrm{FeO}$ at $750-900{ }^{\circ} \mathrm{C}$ and $1-30 \mathrm{~atm}$ in the fuel reactor [61]. Oxygen is fed to the fuel reactor to partially combust the coal and to provide heat for the reduction reactions. The hydrogen generation and oxide regeneration steps are similar to the iron-based SCL process in the hydrogen reactor. The challenges associated with this processes include enhancement of reaction rates and high-temperature solid handling [61]. Another proposed DCL (Figure 3d) is a parallel transformational approach, which integrates coal gasification and the water gas shift reaction (WGS) in two solid particle loops [63]. The first loop gasifies the coal and produces syngas using an oxygen carrier. The second loop converts $\mathrm{CO}$ and $\mathrm{H}_{2} \mathrm{O}$ to $\mathrm{CO}_{2}$ and $\mathrm{H}_{2}$ through the WGS reaction and $\mathrm{CO}_{2}$ capture using a carrier, such as $\mathrm{CaO}$, which is the same as the SCL process. 


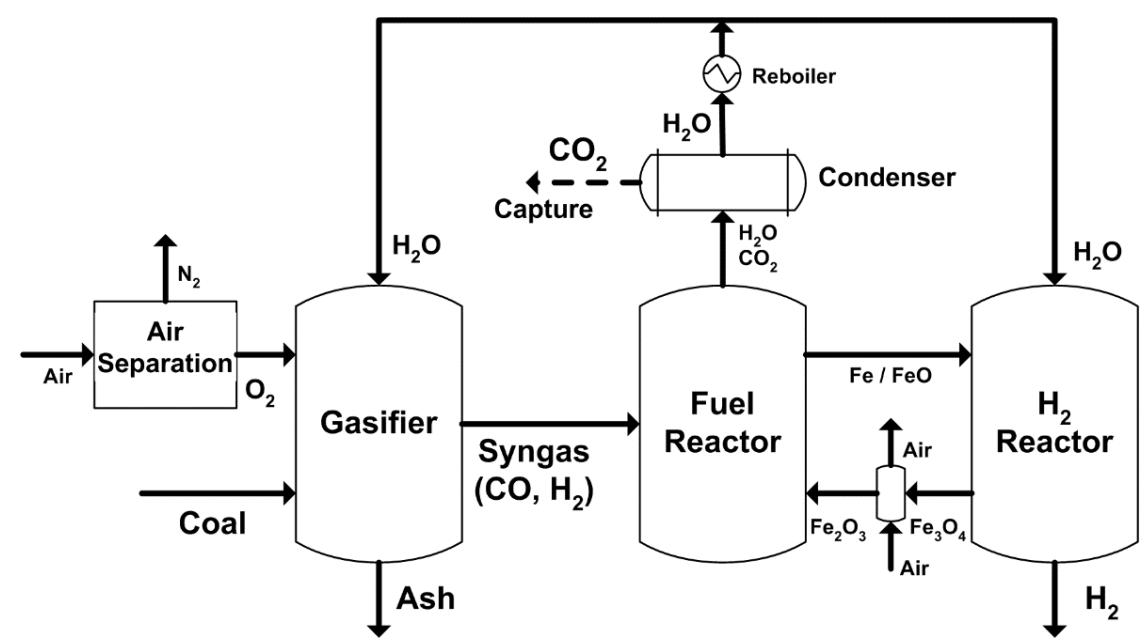

(a)

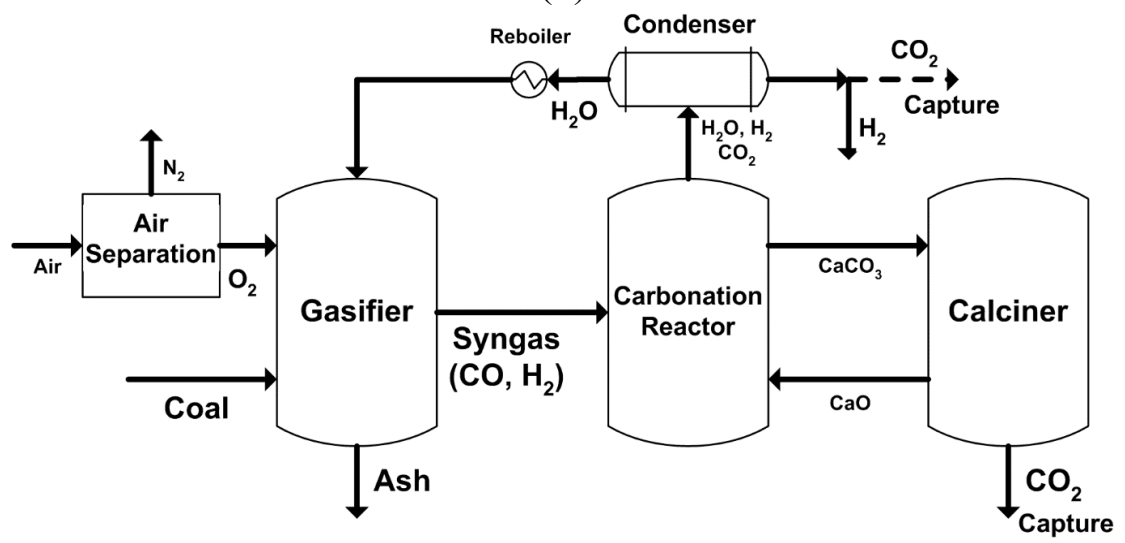

(b)

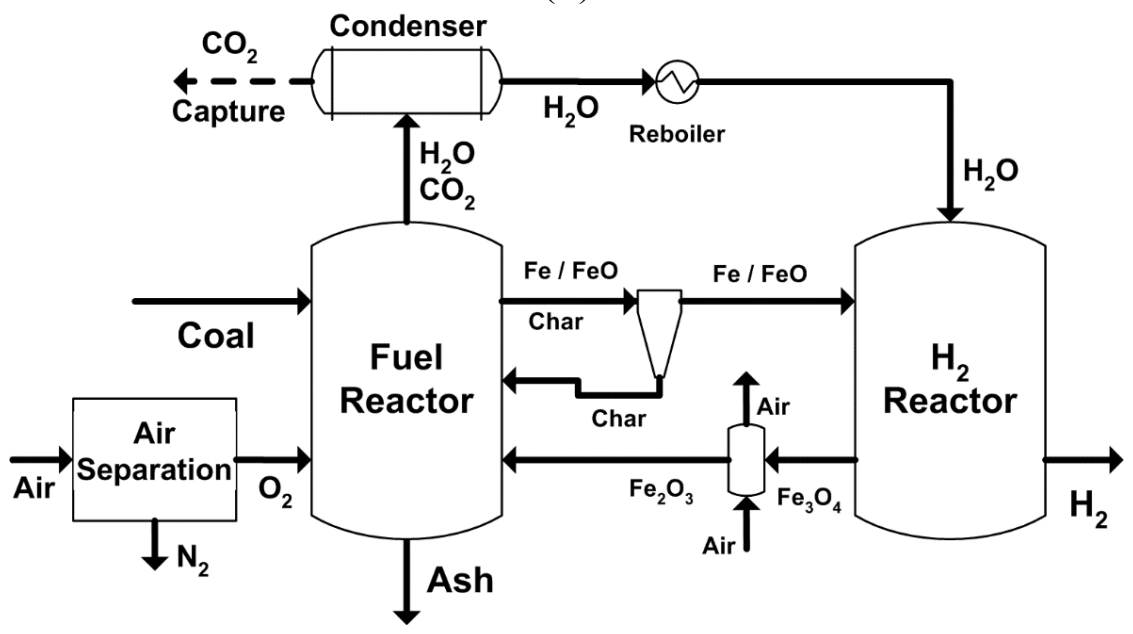

(c)

Figure 3. Cont. 


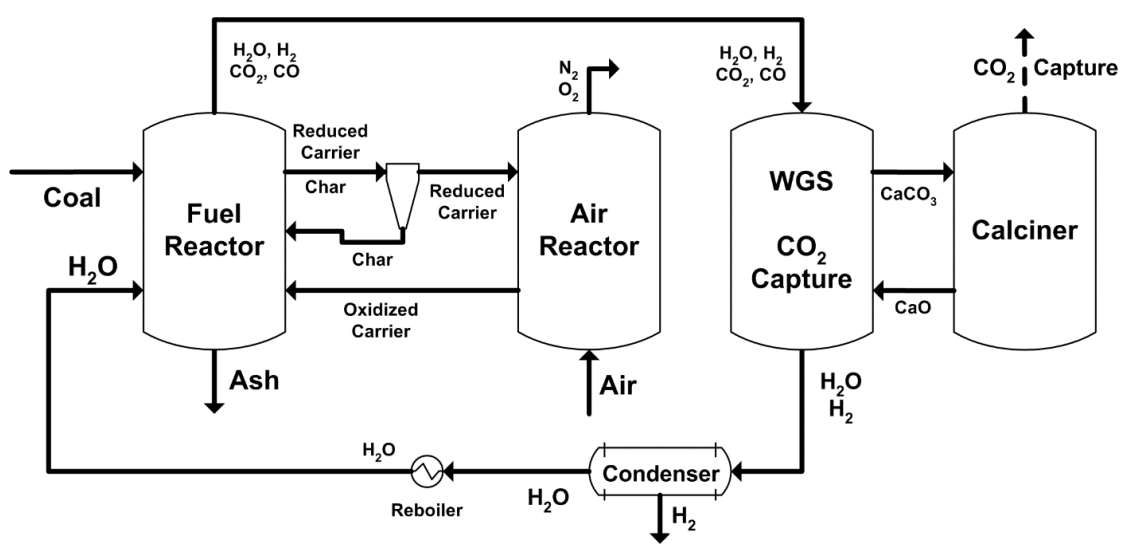

(d)

Figure 3. Major reaction processes of solid fuels in chemical-looping gasification: (a) Iron-based syngas chemical-looping (SCL); (b) Calcium-based SCL and (c) Direct chemical-looping (DCL); and (d) DCL with WGS and $\mathrm{CO}_{2}$ capture [3,61].

In summary, the main reactions in solid fuel CLC and CLG are:

a. devolatilization/pyrolysis;

b. char gasification with steam and/or $\mathrm{CO}_{2}$;

c. char and volatiles combustion;

d. gaseous fuels $\left(\mathrm{H}_{2}, \mathrm{CO}, \mathrm{CH}_{4}\right.$, volatiles $)$ react with oxygen carriers;

e. oxidation of reduced oxygen carriers with air/ $\mathrm{O}_{2}$ or steam.

Kinetic data is often obtained from TGA, fixed bed, and fluidized bed studies. For reaction kinetics, both activation energy and the reaction order are required. The most frequently used kinetic models of gas-solid reactions are the shrinking core model, changing grain size model, and nucleation and nuclei growth models [3].

\section{Oxygen Carriers Development and Application of Thermogravimetric Analysis (TGA)}

TGA is commonly used along with fixed bed and bubbling fluidized bed reactors in the development of CLC technologies. Thermogravimetric analysis has the benefit of fast and cheap testing with the control of experiment conditions, such as temperature and gas environment. Additionally, TGA not only measures sample weight loss but also the evolved gas composition when combined with analysis equipment, such as a mass spectrometer (MS) [27]. However, TGA also faces challenges and has limitations. The heating rate of TGA is generally slow compared to a real CLC reactor. The reactivity of oxygen carriers in a real CLC reactor should be much faster than the reactivity obtained from TGA. Additionally, TGA has limited gas-solid contact resulting in potential mass transfer limitations in chemical looping studies.

TGA has extensively been used to test the reactivity of oxygen carriers (fresh or used) with an isothermal method. In a TGA study, a small amount of oxygen carrier, with or without solid fuel, is typically loaded into a crucible and placed under an inert/reducing $\left(\mathrm{N}_{2}, \mathrm{H}_{2} / \mathrm{N}_{2}\right)$ or an oxidizing (air, $\mathrm{O}_{2} / \mathrm{N}_{2}$ ) gas environment. The reactions mainly take place after the sample temperature is raised to the desired value. Mass and heat transfer limitations are factors affecting the reaction rate in addition to the oxygen carrier and fuel. There are several suggestions to improve mass/heat transfer and the accuracy 
of the tests. The crucible selected for TGA should be as flat as possible or made of a mesh material. For example, a platinum wired mesh basket of $14 \mathrm{~mm}$ diameter and $8 \mathrm{~mm}$ height [45,64]. Initial tests are performed to study the effect of the sample weight and the gas flow rate on the reaction rates in the TGA [45]. Reaction gas may also be pre-heated to the test temperature before being introduced to the TGA [45].

\subsection{Important Oxygen Carrier Characteristics}

Important oxygen carrier characteristics are: (1) sufficient oxygen transport capability; (2) high reactivity for reduction and oxidation reactions and maximum fuel conversion; (3) low attrition and fragmentation to minimize losses of elutriated solids; (4) high melting point to avoid agglomeration and have good fluidization; (5) low cost, which is decisive factor for large scale industrial applications; (6) long lifetime; (7) negligible carbon deposition; and (8) low toxicity and environmentally-friendly characteristics $[3,8,65]$. For inert support materials, stability, surface area, and attrition resistance are important. In the development of oxygen carriers, all of these characteristics should be considered and balanced. Oxygen carrier selection is done based on the fuel (natural gas, coal, biomass, etc.) and the desired chemical-looping process (combustion, gasification, etc.).

For solid fuel chemical-looping processes, primarily oxides of $\mathrm{Ni}, \mathrm{Fe}, \mathrm{Mn}$, and $\mathrm{Cu}$ have been studied [7,14,38,40,41,66-70]. Nickel oxide is expensive and easily deactivated by sulfur from coal. As a result, it is not suitable for solid fuel processes. Fe-based oxygen carriers have been mainly used in iGCLC processes. Iron and manganese oxides are relatively cheap and are also available from natural ores and from industrial waste [31]. Ilmenite is used in many studies because it is cheap, has reasonably high reactivity with syngas in fluidized bed systems, and has good fluidization behavior. Copper oxide has high reactivity and releases gaseous oxygen at high temperature so it is often used in CLOU, even though it is more expensive compared to Fe-based oxygen carriers. Mn-based oxygen carriers can also be used in CLOU. $\mathrm{Mn}$ is cheaper than $\mathrm{Cu}$ but $\mathrm{Mn}$-based materials have a lower rate of oxygen release compared to $\mathrm{Cu}$-based materials [71]. A Cu-based carrier $\left(40 \% \mathrm{CuO} / \mathrm{ZrO}_{2}\right)$ for $\mathrm{CLOU}$ was compared to a Fe-based carrier (ilmenite) for iG-CLC with solid fuels in a fluidized bed [72]. At 95\% conversion of the fuel (coal, petroleum coke or wood char), the conversion rate for CLOU was 3 to 15 factors faster than iG-CLC [72]. Oxygen carriers used for iG-CLC are discussed in more detail in Sections 4.1 and 4.2.

\subsection{Lab Scale TGA Studies for Reactivity and Recyclability of Oxygen Carriers}

TGA is commonly used to screen and characterize oxygen carriers in lab scale studies [73]. Table 1 lists experimental lab scale studies on oxygen carrier development for coal chemical-looping processes using TGA. For the CLOU process, TGA was used to study the oxygen transport capability $\left(R_{o c}\right)$, recyclability, reactivity of reduction and oxidization reactions and the impact of temperature and oxygen concentration on carrier reactivity $[43,73]$. The oxygen transport capability $\left(R_{o c}\right)$ is calculated in Equation 28, where $m_{o x}$ is the mass of the fully oxidized carrier and $m_{r e d}$ is the mass of the reduced carrier ( $\mathrm{CuO}$ has been reduced to $\mathrm{Cu}_{2} \mathrm{O}$ ) [73]. TGA can be used to determine the oxidation and reduction reactivity of the oxygen carriers under controlled conditions [73]. The oxygen carrier oxidation and reduction conversion is shown in Equations 29 and 30, respectively. 
Table 1. Experimental lab scale studies on oxygen carrier development for coal chemical looping process using TGA.

\begin{tabular}{|c|c|c|c|c|c|c|c|}
\hline Oxygen carrier (OC) & Process & Fuel & Sample wt. (mg) & Heating rate $\left({ }^{\circ} \mathrm{C} / \mathrm{min}\right)$ & TGA application & TGA test condition & Ref. \\
\hline \multirow{5}{*}{$\begin{array}{l}60 \text { wt. } \% \mathrm{CuO}+\mathrm{MgAl}_{2} \mathrm{O}_{4} \\
(100-200 \mu \mathrm{m})\end{array}$} & \multirow{5}{*}{ CLOU } & \multirow{5}{*}{ NA } & \multirow{5}{*}{50} & \multirow{5}{*}{ Not reported } & Copper content determination & $15 \% \mathrm{H}_{2} / \mathrm{N}_{2}, 850{ }^{\circ} \mathrm{C}$ & \multirow{5}{*}{73} \\
\hline & & & & & Oxygen transport capacity & $\mathrm{N}_{2}, 1000^{\circ} \mathrm{C}$ & \\
\hline & & & & & $\begin{array}{l}\text { Fresh or used carrier } \\
\text { reactivity, recyclability }\end{array}$ & $\begin{array}{l}\text { Reduction } \mathrm{N}_{2}, 1000^{\circ} \mathrm{C} \text {; oxidation air } 1000^{\circ} \mathrm{C} \\
5 \text { cycles }\end{array}$ & \\
\hline & & & & & $\begin{array}{l}\text { Effect of temperatures on carrier } \\
\text { reactivity }\end{array}$ & $\begin{array}{l}\text { Reduction } \mathrm{N}_{2}, 900^{\circ} \mathrm{C}, 950{ }^{\circ} \mathrm{C}, 1000^{\circ} \mathrm{C} \text {; } \\
\text { oxidation air } 9000^{\circ} \mathrm{C}, 950{ }^{\circ} \mathrm{C}, 1000{ }^{\circ} \mathrm{C}\end{array}$ & \\
\hline & & & & & $\begin{array}{l}\text { Effect of oxygen concentrations } \\
\text { on carrier reactivity }\end{array}$ & $\begin{array}{l}\text { Reduction } \mathrm{N}_{2}, 1000{ }^{\circ} \mathrm{C}, 0,1.5,4 \text {, and } 11 \% \mathrm{O}_{2} \text {; } \\
\text { oxidation air } 900{ }^{\circ} \mathrm{C}, 4,11 \text {, and } 21 \% \mathrm{O}_{2}\end{array}$ & \\
\hline \multirow{2}{*}{$\begin{array}{l}60 \text { wt. } \% \mathrm{NiO} / \mathrm{NiAl}_{2} \mathrm{O}_{4} \\
(125-180 \mu \mathrm{m})\end{array}$} & \multirow[b]{2}{*}{ CLC } & \multirow{2}{*}{$\begin{array}{l}\text { Coal char }(<150 \mu \mathrm{m} \text {, } \\
\text { prepared at } 900^{\circ} \mathrm{C} \\
\text { for } 7 \mathrm{~min})\end{array}$} & \multirow{2}{*}{$\begin{array}{l}10 \\
\text { (OC/char: } 50 / 2-3.5 \text { by mass) }\end{array}$} & \multirow[b]{2}{*}{15} & Reactivity & Reduction $\mathrm{N}_{2}, 900^{\circ} \mathrm{C}$; oxidation air $1000^{\circ} \mathrm{C}$ & \multirow[b]{2}{*}[74]{} \\
\hline & & & & & Recyclability & $\begin{array}{l}\text { Reduction } 50 \% \mathrm{H}_{2} / \mathrm{N}_{2}, 900{ }^{\circ} \mathrm{C} \\
\text { oxidation air } 900{ }^{\circ} \mathrm{C}, 5 \text { cycles }\end{array}$ & \\
\hline Iron ore & IG-CLC & NA & 50 & Not reported & Used carrier reactivity & $15 \% \mathrm{H}_{2} / \mathrm{N}_{2}, 950{ }^{\circ} \mathrm{C}$ & [29] \\
\hline \multirow{2}{*}{$\begin{array}{l}\text { Pure metal oxide } \\
\left(\mathrm{CuO}, \mathrm{Fe}_{2} \mathrm{O}_{3}, \mathrm{Co}_{3} \mathrm{O}_{4}, \mathrm{NiO} \text {, }\right. \\
\left.\text { and } \mathrm{Mn}_{2} \mathrm{O}_{3}\right)\end{array}$} & \multirow[t]{2}{*}{ CLC } & \multirow{2}{*}{$\begin{array}{l}\text { Illinois \#6 } \\
(100 \mu \mathrm{m})\end{array}$} & \multirow{2}{*}{$\begin{array}{l}150 \\
\text { (OC/coal: } 15-22.5 \text { by mass) }\end{array}$} & \multirow[t]{2}{*}{15} & Reactivity & $\begin{array}{l}\text { Reduction } \mathrm{N}_{2} \text { or } \mathrm{CO}_{2}, 700-1000^{\circ} \mathrm{C} \text {; } \\
\text { oxidation air } 900^{\circ} \mathrm{C} \text { or } 1000{ }^{\circ} \mathrm{C} \\
\end{array}$ & \multirow[t]{2}{*}[75]{} \\
\hline & & & & & Recyclability & Fresh coal every cycles, 8 cycles & \\
\hline Pure metal oxide $(\mathrm{CuO})$ & & $\begin{array}{l}\text { Solid fuel (PRB } \\
\text { coal, wood, PE) } \\
(50-150 \mu \mathrm{m})\end{array}$ & $\begin{array}{l}\text { 10-50 (OC/coal: } 75 / 25, \\
\text { OC/PE: } 75 / 25, \\
\text { OC/wood: } 90: 10 \text { by mass) }\end{array}$ & 30 & Reactivity & Reduction $\mathrm{N}_{2}$ or $\mathrm{CO}_{2}, 850^{\circ} \mathrm{C}$ & {$[76]$} \\
\hline
\end{tabular}




$$
\begin{gathered}
R_{o c}=1-\frac{m_{r e d}}{m_{o x}} \\
X_{r e d}=\frac{m_{o x}-m}{m_{o x}-m_{r e d}} \\
X_{o x}=1-X_{\text {red }}=\frac{m-m_{\text {red }}}{m_{o x}-m_{\text {red }}}
\end{gathered}
$$

where $m$ is the mass of the sample at each time; $m_{o x}$ is the mass of the sample fully oxidized, and $m_{\text {red }}$ is the mass of the sample in the reduced form.

The reactivity of single cycle reduction-oxidation reactions for coal char and $\mathrm{NiO} / \mathrm{NiAl}_{2} \mathrm{O}_{4}$ oxygen carriers were tested using TGA [74]. $\mathrm{NiO} / \mathrm{NiAl}_{2} \mathrm{O}_{4}$ oxygen carrier with $60 \% \mathrm{NiO}$ by mass (N6AN1306) and particle sizes of 125-180 $\mu \mathrm{m}$ was prepared using a sol-gel method. Coal with particle sizes under $150 \mu \mathrm{m}$ was heated in an electric muffle furnace at $900{ }^{\circ} \mathrm{C}$ for $7 \mathrm{~min}$ to make coal char. The coal char and oxygen carrier mixture $(\sim 10 \mathrm{mg})$ with a char to oxygen carrier mass ratio of 3:50 was used. Using an isothermal method, the reduction and oxidation reactions were conducted at $900{ }^{\circ} \mathrm{C}$ in $\mathrm{N}_{2}$ and at $1000{ }^{\circ} \mathrm{C}$ in air, respectively. The sample was first heated to $900{ }^{\circ} \mathrm{C}$ at a heating rate of about $15{ }^{\circ} \mathrm{C} / \mathrm{min}$ under $\mathrm{N}_{2}$ with a gas flow rate of $100 \mathrm{~mL} / \mathrm{min}$ then held at that temperature. When the sample weight was nearly constant, air was added to the TGA and the temperature was increased to $1000{ }^{\circ} \mathrm{C}$. Figure 4 shows the sample weight percentage of the initial weight $v s$. time in black and temperature $v s$. time in red [74]. In $\mathrm{N}_{2}$, the sample weight started to decrease rapidly around $850^{\circ} \mathrm{C}$, which means that char reacted with oxygen carriers at high temperature $>850{ }^{\circ} \mathrm{C}$. The reaction generates gases $\left(\mathrm{H}_{2} \mathrm{O}\right.$ and $\left.\mathrm{CO}_{2}\right)$ and reduced $\mathrm{Ni}$ (Reaction 31) with a theoretical weight loss $83.3 \%$. The final char and oxygen carrier after $180 \mathrm{~min}$ lost approximately $86.5 \%$ of the initial weight in $\mathrm{N}_{2}$ At these conditions, the reduction reaction is considered to be nearly complete. After air was added, the sample weight first decreased rapidly due to the residual char combustion with $\mathrm{O}_{2}$, then increased rapidly to $96 \%$ when the reduced $\mathrm{Ni}$ oxidized by reacting with $\mathrm{O}_{2}$ in the air (Reaction 32 ).

$$
\begin{gathered}
\mathrm{NiO}+\mathrm{C}_{x} \mathrm{H}_{y} \mathrm{O}_{z} \rightarrow \mathrm{Ni}+\mathrm{CO}_{2(\mathrm{~g})}+\mathrm{H}_{2} \mathrm{O}_{(\mathrm{g})} \\
\mathrm{Ni}+1 / 2 \mathrm{O}_{2} \rightarrow \mathrm{NiO}
\end{gathered}
$$

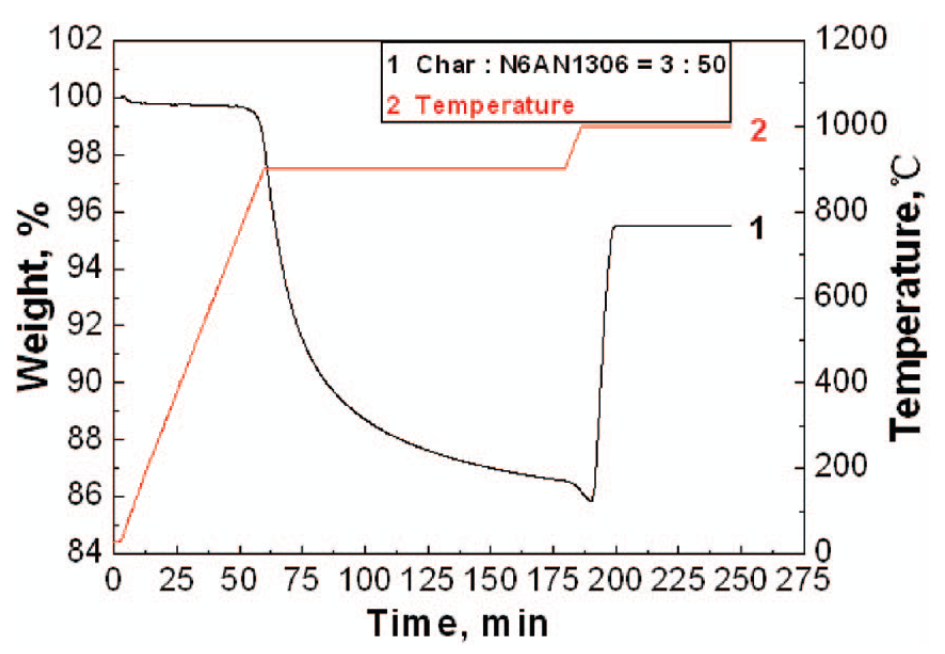

Figure 4. Weight change (TG) of single cycle reduction-oxidation reactions of coal char and $\mathrm{NiO} / \mathrm{NiAl}_{2} \mathrm{O}_{4}$ oxygen carriers [74]. 
Multiple-cycle TGA reduction-oxidation reactions of $\mathrm{NiO} / \mathrm{NiAl}_{2} \mathrm{O}_{4}$ oxygen carrier (N6AN1306) were tested at $900{ }^{\circ} \mathrm{C}$ in $50 \% \mathrm{H}_{2} / \mathrm{N}_{2}$ for reduction and oxidation in air. Hydrogen was used to reduce the oxygen carrier instead of coal char because the cyclic feed of char particles is impossible using TGA. Another problem with testing multiple-cycle reduction-oxidation reactions in TGA is the difficult separation of ash from the residual oxygen carrier particles. Interaction between the ash and oxygen carriers may take place in TGA. Although TGA is not ideal for cyclic reduction-oxidation reaction studies, this method can provide useful information for evaluating oxygen carriers with coal char and the physical performance of the oxygen carrier [74]. In this test, the oxygen carrier was heated to $900{ }^{\circ} \mathrm{C}$ in $50 \% \mathrm{H}_{2} / \mathrm{N}_{2}$ and held at that temperature until the weight of carrier remained constant. After the reduction reaction was finished, the TGA reaction chamber was filled with inert gas $\mathrm{N}_{2}$ to purge out any remaining hydrogen. The oxidation reaction was started by feeding air into the TGA at $900{ }^{\circ} \mathrm{C}$. This cycle of reduction and oxidation was repeated five times. Figure 5 shows the carrier mass changes $v s$. time in black and the temperature $v s$. time in red during the test. The sample mass (percentage of initial sample) after each reduction cycle was $87.40 \%, 87.07 \%, 86.82 \%, 86.68 \%$, and $86.54 \%$, respectively. The overall reduction of the sample increased gradually, which may be due to the formation of large inner pores from thermal shock and chemical reaction. Similarly, the overall oxidation of the sample decreased gradually. The sample mass after each oxidation cycle was $100.07 \%, 99.88 \%, 99.71 \%$, $99.61 \%$, and $99.58 \%$, respectively. This may be caused by the volatilization of parts of the metal $\mathrm{Ni}$ during the reaction cycles. The differences between the oxidized mass and the reduced mass at each cycle were $12.67 \%, 12.81 \%, 12.89 \%, 12.93 \%$, and $13.04 \%$, respectively. As a result, the reactivity of the oxygen carrier increased slightly over the five-cycle reduction-oxidation tests [74].

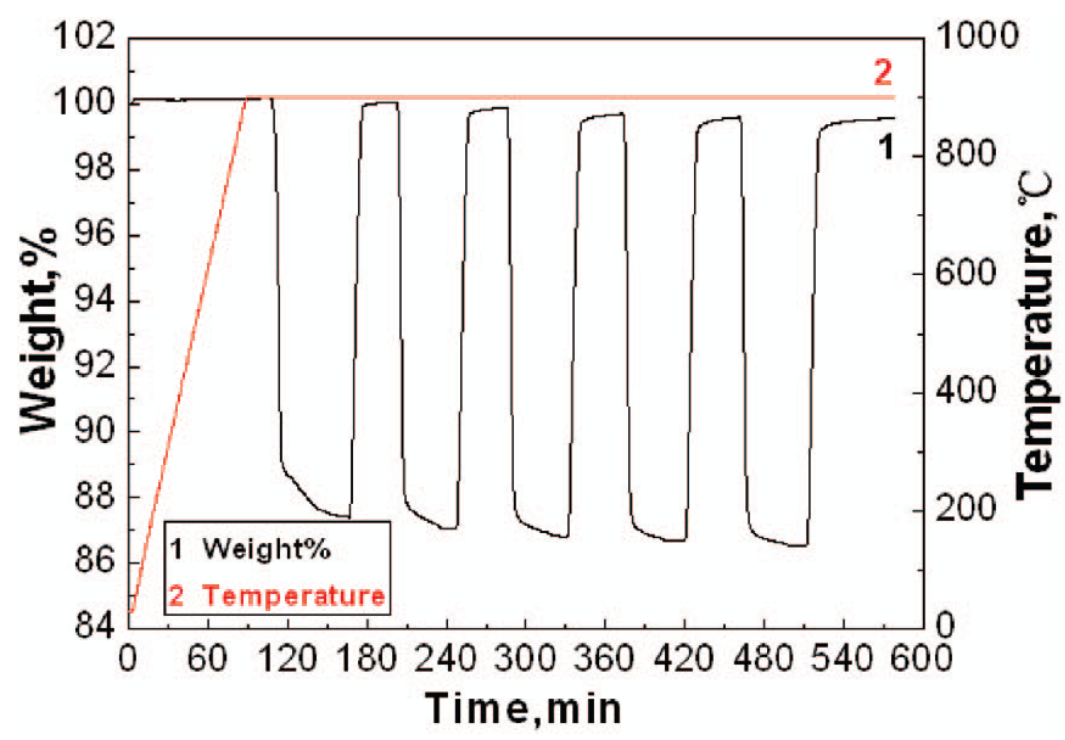

Figure 5. Weight change (TG) of multiple cycle reduction-oxidation reactions of $\mathrm{NiO} / \mathrm{NiAl}_{2} \mathrm{O}_{4}$ oxygen carriers and hydrogen/air [74].

\subsection{Comparison of Oxygen Carrier Reactivity Using TGA with Large Scale Fluidized Bed Studies}

Large scale chemical-looping studies use two interconnected fluidized beds in both batch and continuous configurations. Comparison studies using TGA may provide helpful information on the reactivity of fresh and used oxygen carriers $[29,73,77]$. A continuous $500 \mathrm{Wth}$ iG-CLC unit, consisting 
of two interconnected fluidized bed reactors and a fluidized bed loop seal, has been used for CLC [29]. Tiega iron ore from a hematite mine in Tiega (Zaragoza, Spain), a low cost oxygen carrier, and various coals (lignite, bituminous, and anthracite) were tested at $875-930^{\circ} \mathrm{C}$. The oxygen demand of the Tiega iron ore was lower than two other promising Fe-based oxygen carriers: ilmenite and a Fe-enriched sand fraction from alumina production (Fe-ESF). All three carriers were tested in the same unit. The high reactivity of Tierga iron ore with gases present in the fuel reactor $\left(\mathrm{CO}, \mathrm{H}_{2}, \mathrm{CH}_{4}\right)$ may be a reason for its lower oxygen demand. This is especially true when compared to the ilmenite [29]. The high CaO content of Tiega iron ore may also enhance coal gasification and result in the higher reactivity [78,79]. TGA was used to test fresh and used oxygen carrier reactivity. The reduction reaction was conducted in $15 \% \mathrm{H}_{2} / \mathrm{N}_{2}$ at $950{ }^{\circ} \mathrm{C}$ [29]. The results of this study showed no reactivity changes between activated and $50 \mathrm{~h}$ used iron ore.

\subsection{Kinetic Studies of Oxygen Carriers and Solid Fuels Using TGA}

TGA has been used extensively to study the reduction and oxidation kinetics for oxygen carriers along with fixed bed and batch fluidized bed reactors. The reaction kinetics are mainly affected by the choice of oxygen carrier, particle size (both oxygen carriers and solid fuels, $70 \mu \mathrm{m}$ to $2 \mathrm{~mm}$ ), temperature $\left(600-1000^{\circ} \mathrm{C}\right)$, and fuel [10]. In general, the reactivity of $\mathrm{Cu}, \mathrm{Ni}$, and $\mathrm{Co}$ oxides is higher than that of Fe. Oxygen carriers prepared by impregnation methods typically have higher reactivity compared to carriers prepared by physical mixing methods. This occurs because the preparation method may affect the degree of dispersion of the active phase (e.g., $\mathrm{CuO}$ ) on inert support materials in the oxygen carrier $[64,80]$. The active phase tended to concentrate on a particle's exterior and accumulated more as the active phase increased [80]. The impregnated carrier may have a slightly higher degree of dispersion of the active phase than the physically mixed carrier. Adábez-Rubio et al. studied the kinetics of $\mathrm{Cu}$-based oxygen carriers $(\mathrm{Cu} 60 \mathrm{MgAl})$ for $\mathrm{CLOU}$ using TGA [46]. The reduction of $\mathrm{CuO}$ to $\mathrm{Cu}_{2} \mathrm{O}$ was done under a mixture of $\mathrm{N}_{2}+\mathrm{O}_{2}$ and the oxidation of $\mathrm{Cu}_{2} \mathrm{O}$ to $\mathrm{CuO}$ was done under $\mathrm{O}_{2}$. To calculate the activation energy of these reactions, the effect of temperature on reaction rate must be evaluated. For $\mathrm{CuO} / \mathrm{Cu}_{2} \mathrm{O}$ systems in $\mathrm{CLOU}$, reduction is typically done in the temperature range of $875-1000{ }^{\circ} \mathrm{C}$ and oxidation is done between $850-1000^{\circ} \mathrm{C}$. The oxygen carrier conversion was calculated for reduction and oxidation as shown in Equations (29) and (30), respectively. The reaction rate for reduction and oxidation are calculated from TGA conversion data using Equations (33) and (34), respectively.

$$
\begin{gathered}
\left(-r_{r e d}\right)_{o c}=R_{o c} \frac{d X_{r e d}}{d_{t}} \\
\left(r_{o x}\right)_{o c}=R_{o c} \frac{d X_{o x}}{d_{t}}
\end{gathered}
$$

where $R_{o c}$ is the oxygen transport capability, $X$ is the oxygen carrier conversion, and $t$ is the time. From the conversion $v s$. time curves for reduction and oxidation, at various temperatures, the maximum reaction rate may be calculated. The reduction reaction rate is given by Equation (35):

$$
\left(-r_{\text {red }}\right)_{o c}=k_{1} f(X)
$$

where $k$ is the temperature dependent kinetic constant and $f(X)$ is the oxygen carrier conversion. The global activation energy for these reactions is obtained from the Arrhenius relationship between $r$ and 
temperature. To study the impact of oxygen concentration on reaction rates, the $\mathrm{O}_{2}$ concentration was selected between 0-9 vol \% for reduction and 1.5-21 vol \% for oxidation. The reaction rate is presented in Equation (36):

$$
\left(-r_{\text {red }}\right)_{o c}=k_{2}\left(C_{O_{2}, e q}-C_{O_{2}}\right) f(X)
$$

where $\mathrm{Co}_{2}$ is the $\mathrm{O}_{2}$ concentration at each time and $\mathrm{Co}_{2, e q}$ is the $\mathrm{O}_{2}$ concentration at equilibrium. Equations 35 and 36 are also valid for oxidation reactions. Typical activation energies for reduction and oxidation are approximately $270 \mathrm{~kJ} / \mathrm{mol}$ and $32 \mathrm{~kJ} / \mathrm{mol}$, respectively [46]. The reaction order was 0.5 for reduction and 1.2 for the oxidation. The nucleation and nuclei growth model with chemical reaction control was used to describe the oxygen carrier conversion with time. A Langmuir-Hinshelwood model was used to investigate the effect of the oxygen concentration on reduction and oxidation reaction rates.

Experimental results and kinetics obtained from TGA provide some useful information for the design and operation of chemical-looping process. However, it cannot be directly applied to real reactors in chemical-looping due to the low heating rate of TGA. The TGA heating rates are typically less than $200{ }^{\circ} \mathrm{C} / \mathrm{min}$. Most proposed reactors for chemical-looping are fluidized beds. The heating rate in a fluidized bed $\left(\sim 1000^{\circ} \mathrm{C} / \mathrm{sec}\right)$ is typically higher than TGA $\left(\sim 100^{\circ} \mathrm{C} / \mathrm{min}\right)$. Oxygen carrier/fuel particles take a much short time in a fluidized bed $(\sim 1 \mathrm{~s})$ to reach the reaction temperature $\left(1000{ }^{\circ} \mathrm{C}\right)$ compared to a TGA $(\sim 10 \mathrm{~min})$. As a result, the actual reactivity of oxygen carriers in a CLC reactor should be much faster than the reactivity obtained from TGA [76].

\section{Challenges and Research on Direct Coals Chemical-Looping Combustion}

There are several critical issues with the coal-direct chemical-looping process. These issues are oxygen carrier particle reactivity, char reaction enhancement, gas and solid conversion, the fate of pollutants and ash, heat management, and integration [4]. Sulfur contained in coals may play an important role in the CLC process because sulfur poisons the oxygen carrier activity. The effect of sulfur on the oxygen carrier requires further study in the future $[3,26]$. Separating ash from the oxygen carrier is also a challenging issue. One of the most promising approaches is to use cheap oxygen carriers, such as natural minerals or industrial waste products, so the ash and oxygen carrier may be discarded together $[16,66]$.

\subsection{Challenges and Recent Research on the iG-CLC Process}

The selection of a suitable oxygen carrier is a key factor for CLC technology development. Oxygen carriers based on $\mathrm{Fe}, \mathrm{Ni}$, and $\mathrm{Cu}$ for mainly gaseous fuels have been extensively investigated and reviewed by Adanez et al. [3] and Hossain and de Lasa [8]. These oxygen carriers have been investigated for coal iG-CLC because coal is first pyrolyzed/gasified to syngas and then the syngas reacts with the metal oxide. For large scale industrial applications of coal CLC, the availability of low cost oxygen carriers is very important. Low cost oxygen carriers with sufficient reactivity for the coal CLC are preferred due to coal ash. Ash may deactivate the oxygen carrier or cause loss of oxygen carrier with the ash when it is separated from the oxygen carrier. Natural minerals and industrial wastes from industrial steel and alumina processes are inexpensive and attractive oxygen carriers for coal CLC. 
In a lab-scale batch fluidized bed reactor, ilmenite $\left(\mathrm{FeTiO}_{3} / \mathrm{Fe}_{2} \mathrm{TiO}_{5}\right)$ and a synthetic $\mathrm{Fe}$ based oxygen carrier ( $60 \mathrm{wt} \% \mathrm{Fe}_{2} \mathrm{O}_{3}$ and $40 \mathrm{wt} \% \mathrm{MgAl}_{2} \mathrm{O}_{4}$ ) with solid fuels (five coals and one petroleum coke) were investigated at $950{ }^{\circ} \mathrm{C}$ with $50 \%$ of $\mathrm{H}_{2} \mathrm{O}$ [12]. Figure 6 showed the produced gas concentrations after condensations water $v s$. time during the reduction of $40 \mathrm{~g} \mathrm{Fe}_{2} \mathrm{O}_{3} / \mathrm{MgAl}_{2} \mathrm{O}_{4}$ (a) and $40 \mathrm{~g}$ ilmenite (b) with $0.2 \mathrm{~g}$ petroleum coke. The two carriers had similar the concentrations $\left(\mathrm{CO}_{2}, \mathrm{CH}_{4} / \mathrm{SO}_{2}\right.$, and $\left.\mathrm{CO}\right)$. The ilmenite and synthetic oxygen carriers reacted well with all fuels and showed similar reactivity. The surface of both fresh and used carriers was analyzed in a scanning electron microscope (SEM). Both of the used carriers had rougher surface compared to the fresh ones. The BET surface area of the used ilmenite increased to $0.58 \mathrm{~m}^{2} / \mathrm{g}$ from the fresh ilmenite $0.11 \mathrm{~m}^{2} / \mathrm{g}$. For the synthetic carrier, the surface area of used one decreased to $0.76 \mathrm{~m}^{2} / \mathrm{g}$ from the fresh one $8.58 \mathrm{~m}^{2} / \mathrm{g}$. All of them mean the interior particle structure changes for both carriers. The synthetic carrier had sintering problems which also occurred for gaseous fuels [70] but its reactivity interestingly remains high. There was no agglomeration for the synthetic carrier but minor agglomeration for the ilmenite. This agglomeration happened at the high temperature of $1000{ }^{\circ} \mathrm{C}$ during a period of defluidization. Companhia ValedoRio Doce (CVRD) iron ore with a bituminous coal was investigated in a laboratory fixed bed with pressure (0.1-0.6 MPa) at $970{ }^{\circ} \mathrm{C}$ [81]. High pressure improved gas conversion with CVRD iron ore. By increasing pressure, higher $\mathrm{CO}_{2}$ concentration and lower fractions of $\mathrm{CO}, \mathrm{CH}_{4}$, and $\mathrm{H}_{2}$ were obtained. After several cycles, the particles were analyzed using a scanning electron microscope and energy dispersive X-ray spectroscopy (SEM-EDX). The particle became porous but the structure and size of particles maintained same. The crystalline phase had no changes even though there was very little coal ash deposited on the carrier.

Natural minerals and industrial waste from industrial steel and alumina processes have been tested in pilot scale reactors. Selected coal iG-CLC tests in two interconnected continuous fluidized bed (CFB) reactors $(0.5-100 \mathrm{~kW})$ are listed in Table 2 . The following is a summary of these iG-CLC tests. A Norwegian ilmenite oxygen carrier (natural iron-titanium oxide) and coals (lignite, bituminous, and anthracite) were tested in a $0.5 \mathrm{KW}_{\text {th }}$ continuous $\mathrm{CFB}$ reactor at Instituto de Carboquímica (ICB-CSIC) $[6,39,50]$. The same unit and coals were also used to evaluate Fe-enriched sand fraction (Fe-ESF) oxygen carrier, generated in the alumina production from bauxite [28] and Tiega iron ore from a hematite mine in Tiega (Zaragoza, Spain) [29]. The results showed that all these three are the promising Fe based oxygen carriers oxygen for coal combustion. Tiega iron ore has higher reactivity compared to other two carriers of ilmenite and Fe-ESF. Australian natural iron ore with Shenhua bituminous coal and sawdust were also tested in a $1 \mathrm{KW}_{\text {th }} \mathrm{CFB}$ reactor [26,38,52]. Nickel-based oxygen carrier $\left(\mathrm{NiO} / \mathrm{Al}_{2} \mathrm{O}_{3}\right)$ was tested with Shenhua bituminous coal in a $10 \mathrm{KW}$ th $\mathrm{CFB}$ reactor [68]. Ilmenite and manganese were tested with bituminous coal and petcoke in a $10 \mathrm{KW}_{\text {th }} \mathrm{CFB}$ unit at Chalmers University of Technology [9,53]. Ilmenite was also tested with Colombian bituminous coal in a $100 \mathrm{KW}$ th CFB unit with a circulating fluidized bed fuel reactor [51]. Among the tested oxygen carriers, ilmenite with iron oxide as the active phase has been extensively tested. Ilmenite has high conversion to syngas ( $\mathrm{CO}$ and $\mathrm{H}_{2}$ ) and moderate $\mathrm{CH}_{4}$ conversion in a batch fluidized bed [11]. Ilmenite reactivity for fuel gases $\left(\mathrm{H}_{2}, \mathrm{CO}\right.$, and $\left.\mathrm{CH}_{4}\right)$ is higher after calcination and activation than fresh ilmenite [82]. 
Table 2. Pilot scale tests of the coal direct CLC process in two interconnected continuous fluidized beds reactors.

\begin{tabular}{|c|c|c|c|c|c|}
\hline Oxygen carrier & Fuel & Process & Size $(\mathrm{kW})$ * & $\begin{array}{l}\text { Temperature } \\
\text { in fuel reactor }\end{array}$ & Reference \\
\hline Ilmenite & \multirow{3}{*}{$\begin{array}{l}\text { Lignite bituminous, } \\
\text { anthracite coal }\end{array}$} & \multirow{3}{*}{ iG-CLC } & \multirow{3}{*}{0.5} & $870-950^{\circ} \mathrm{C}$ & {$[6,39,50]$} \\
\hline Bauxite waste (Fe-based) & & & & \multirow{2}{*}{$870-930^{\circ} \mathrm{C}$} & {$[15,28]$} \\
\hline Tiegra iorn ore & & & & & [29] \\
\hline $\begin{array}{l}\text { Ilmenite, } \\
\text { manganese }\end{array}$ & Bituminous coal, petcoke & iG-CLC & 10 & $950^{\circ} \mathrm{C}$ & {$[9,33,53]$} \\
\hline Ilmenite & Bituminous coal & iG-CLC & 100 & $940-980^{\circ} \mathrm{C}$ & {$[51]$} \\
\hline $\mathrm{NiO} / \mathrm{A} 12 \mathrm{O} 3$ & Shenhua Bituminous coal & iG-CLC & 10 & $870-970{ }^{\circ} \mathrm{C}$ & {$[68,69]$} \\
\hline Iron ore & Shenhua Bituminous coal and/or sawdust & iG-CLC & 1 & $900-980^{\circ} \mathrm{C}$ for coal & {$[26,38,40,52]$} \\
\hline $\begin{array}{l}60 \% \mathrm{CuO} \text { with } \mathrm{MgAl}_{2} \mathrm{O}_{4} \text { as } \\
\text { support }(\mathrm{Cu} 60 \mathrm{MgAL})\end{array}$ & Bituminous coal & CLOU & 1.5 & & [43] \\
\hline
\end{tabular}

* Thermal energy by designed/perfect combustion of fuel.
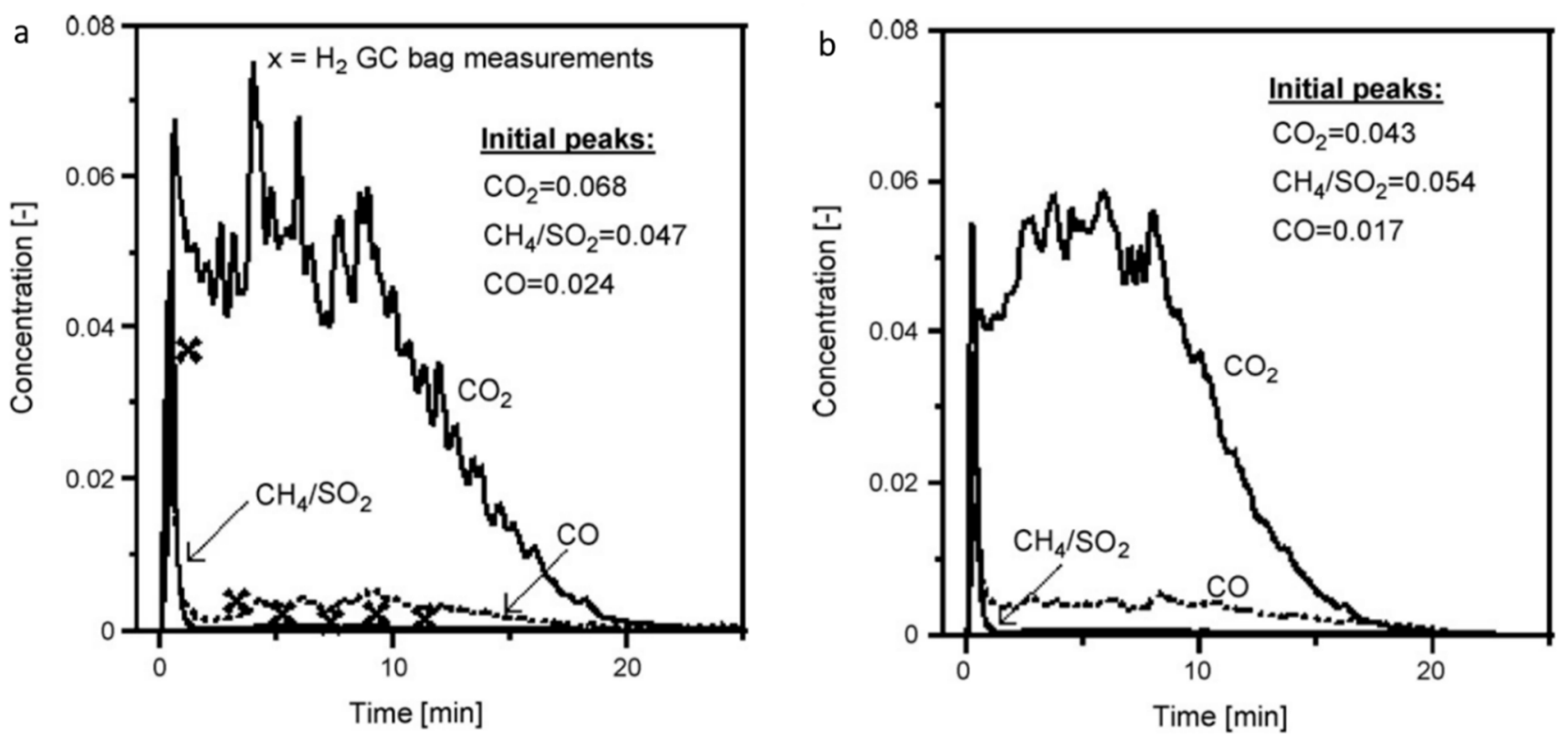

Figure 6. Produced gas concentrations after condensations water vs. time during the reduction of $40 \mathrm{~g} \mathrm{Fe}_{2} \mathrm{O}_{3} / \mathrm{MgAl}_{2} \mathrm{O}_{4}$ (a) and $40 \mathrm{~g}$ ilmenite (b) with $0.2 \mathrm{~g}$ petroleum coke at $950{ }^{\circ} \mathrm{C}$ with $50 \%$ of $\mathrm{H}_{2} \mathrm{O}$ [12].

For the CLC applied in the $\mathrm{CO}_{2}$ emission control, process performance is mainly evaluated by $\mathrm{CO}_{2}$ capture efficiency along with the system behavior. The $\mathrm{CO}_{2}$ capture efficiency ( $\left.\eta \mathrm{co}_{2}\right)$ is defined as the ratio of $\mathrm{CO}_{2}$ flow leaving the fuel reactor $(\mathrm{FcO} 2, \mathrm{FR})$ to the total carbonaceous gas flow leaving both the fuel and air reactors $(\mathrm{Fc}, \mathrm{FR}+\mathrm{Fc}, \mathrm{AR})$ by Equation 37 [68]:

$$
\eta_{\mathrm{co}_{2}}=\frac{\mathrm{F}_{\mathrm{CO}_{2}, \mathrm{FR}}}{\mathrm{F}_{\mathrm{C}, \mathrm{FR}}+\mathrm{F}_{\mathrm{C}, \mathrm{AR}}}
$$

For the coal iG-CLC, the reactions in the fuel reactor are shown in Figure 7. From this figure, the reaction $\eta \mathrm{co}_{2}$ is dependent on the gas conversion and coal char conversion. If unconverted gases 
$\left(\mathrm{CO}, \mathrm{CH}_{4}\right)$ leave with the gas stream from the fuel reactor, the gases conversion and $\eta \mathrm{co} 2$ will be low. The gas conversion for iG-CLC pilot tests are typically $75 \%-95 \%$ and depend on the coal, oxygen carrier, and solid inventory $[13,38,40,66]$. Complete conversion of the gases, including volatiles and syngas, is difficult. The outlet gases from the fuel reactor for the test of a $1 \mathrm{KW}$ coal iG-CLC using iron ore were typically $1 \% \mathrm{CH}_{4}, 4 \% \mathrm{CO}$, and $95 \% \mathrm{CO}_{2}$ [52]. While gas conversion is dependent on the reactivity of the oxygen carrier, it is most affected by the mixing between the particles and the residence time of the gases produced in the fuel reactor [9]. The gas generated in the upper regions of the fuel reactor may have insufficient contact with the oxygen carrier compared to gases generated at the bottom of the reactor [13]. Oxygen polishing is one of the proposed approaches to completely convert product gases by introducing pure oxygen at the outlet of the fuel reactor. Another approach is to recycle the unconverted gases back into the fuel reactor by separating them using $\mathrm{CO}_{2}$ liquefaction [51]. If unconverted char is transferred with the reduced oxygen carrier to the air reactor, the efficiency of carbon capture will decrease. Char conversion is dependent on the fuel conversion rate, which is affected by fuel reactivity, particle size, and reaction temperature [9]. One approach is to use a carbon stripper to separate or gasify the unconverted carbon with the reduced oxygen carrier and send back to the fuel reactor [51]. The separation of unconverted char and reduced oxygen carrier is based on different rates of elutriation for the fuel particles and the carrier. The fuel particles have lower density and smaller size at this stage.

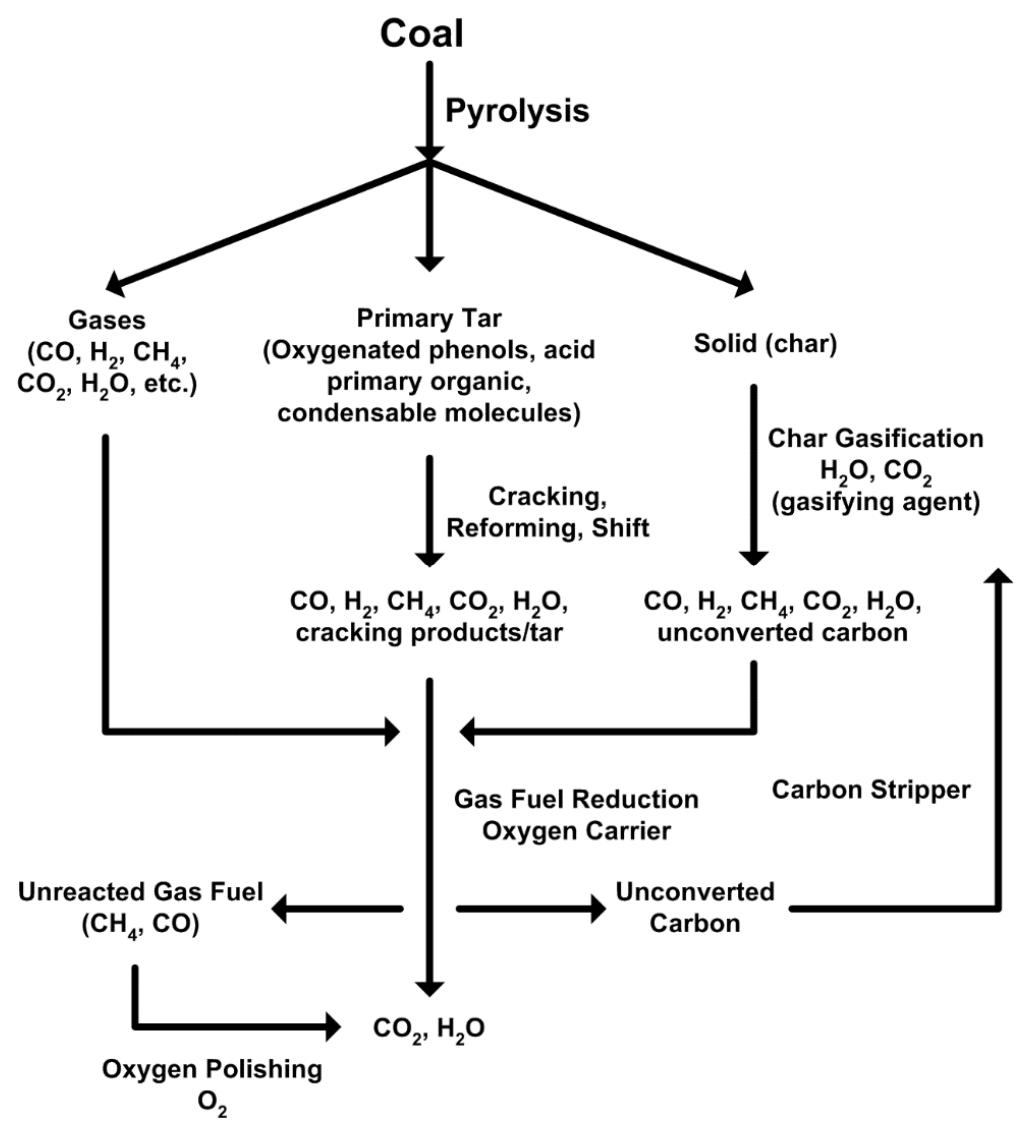

Figure 7. Coal reactions in the fuel reactor for iG-CLC.

Oxygen-carriers have been tested in chemical-looping combustion and gasification processes for solid fuels (coal, petroleum coke, biomass) [9,13,16,18-20]. From Table 2, bituminous coal is commonly used 
in the pilot scale tests due to its high reactivity. Different types of lignite, highly volatile bituminous coal, medium volatile bituminous coal, and anthracite were evaluated in situ gasification chemical-looping processes using an ilmentite oxygen carrier [6]. The carbon capture efficiency decreased as the coal rank increased following lignite, bituminous, and anthracite. This is due to the high coal reactivity for low rank coal with fast char gasification rates and high volatile content. Results also showed that the combustion efficiency in the fuel reactor is not limited by the reaction rate of ilmenite but it is limited by the low conversion of volatile matter. In gasification, volatiles (gas and tar) and char react with the oxidant that surrounds the coal particles along with synthesis gas. The conversion of volatiles may not be complete in the gasification/reducing environment, but will be complete in the combustion environment with excess of oxygen. Volatiles in the fuel reactor are under a reducing environment and may not achieve complete conversion. As a result, research is needed to investigate the volatile reactions under chemical-looping condition for coals with different volatile content.

The rate of gasification is a function of temperature, pressure, gas composition, and the nature of the coal. To enhance the carbon conversion, $\mathrm{H}_{2} \mathrm{O}$ and/or $\mathrm{CO}_{2}$ is commonly used as carrier gas for solid fuels. $\mathrm{CO}_{2}$ and steam gasification reactions are endothermic and thermodynamically favored at higher temperatures [83]. Hydrogen gasification (methanation reaction) is exothermic and thermodynamically favored at low temperature $\left(<670{ }^{\circ} \mathrm{C}\right)$ (Reaction 38) [83]. In iG-CLC, the operating temperature is typically higher than $860^{\circ} \mathrm{C}$ (from Table 2 ), so $\mathrm{CH}_{4}$ is generated in the volatiles.

$$
\begin{gathered}
\mathrm{C}_{(\mathrm{s})}+2 \mathrm{H}_{2(\mathrm{~g})} \leftrightarrow \mathrm{CH}_{4(\mathrm{~g})} \\
\Delta \mathrm{H}^{\circ}{ }_{298 \mathrm{~K}}=-74.8 \mathrm{~kJ} / \mathrm{mol}
\end{gathered}
$$

The pilot scale test also showed that high operating temperature resulted in high carbon capture and combustion efficiencies for all coal ranks [6]. Cuadrat et al. [6] studied the feasibility of using $\mathrm{H}_{2} \mathrm{O}$ and $\mathrm{CO}_{2}$ mixtures as the gasifying agent for iG-CLC with different rank coals and ilmenite. $\mathrm{CO}_{2}$ can be used in place of steam as a gasifying agent for bituminous and lignite coals because the high reactivity of low rank coals overcomes the slower gasification rate with $\mathrm{CO}_{2}$. The reverse reaction of char $\mathrm{CO}_{2}$ gasification is a carbon deposition reaction that causes carbon fouling on solid surfaces resulting in catalyst/oxygen carrier deactivation. Excess steam is often used to alleviate carbon fouling and loss of catalyst/oxygen carrier activity [58].

In the iG-CLC process, increasing the char gasification rate is a major challenge because char gasification is the rate limiting step since it is slower than the syngas reaction with the carrier [5]. Oxygen carriers can affect the rate of char gasification. Brazilian manganese ore was investigated in a batch fluidized-bed reactor using petroleum coke, coal, and wood char as fuel with a $50 \% \mathrm{H}_{2} \mathrm{O}$ in $\mathrm{N}_{2}$ fluidizing gas. The performance of this manganese ore was compared to ilmenite [34]. Results showed that the rate of char gasification using manganese ore was higher than ilmenite. Alkali and alkaline-Earth metal salts or oxides are known to catalyze coal char steam gasification. The order of catalytic activity is $\mathrm{K}_{2} \mathrm{SO}_{4}$ or $\mathrm{K}_{2} \mathrm{CO}_{3}>\mathrm{Na}_{2} \mathrm{CO}_{3}>\mathrm{KCl}>\mathrm{NaCl}>\mathrm{CaCl}_{2}$ or $\mathrm{CaO}[84]$. For the iG-CLC, additives $\left(\mathrm{CaO}, \mathrm{CaCO}_{3}\right.$, and $\mathrm{K}_{2} \mathrm{CO}_{3}$ ) are used to enhance the rate of char conversion [37,38,53,85,86]. These additives are mechanically mixed with the oxygen carriers or impregnated on the oxygen carrier particles $[38,40]$. Song et al. combined calcium aluminate cement with hematite $\left(77.3 \% \mathrm{Fe}_{2} \mathrm{O}_{3}, 12 \% \mathrm{SiO}_{2}\right.$, and $10 \% \mathrm{Al}_{2} \mathrm{O}_{3}$ by wt.) producing an oxygen carrier $\left(\mathrm{Ca}_{2} \mathrm{Al}_{2} \mathrm{SiO}_{7}\right)$ in the presence of $\mathrm{CaO}, \mathrm{Al}_{2} \mathrm{O}_{3}$, and $\mathrm{SiO}_{2}$. The calcium aluminate cement $\left(51.08 \% \mathrm{Al}_{2} \mathrm{O}_{3}, 33.12 \% \mathrm{CaO}, 7.8 \% \mathrm{SiO}_{2}\right.$ by wt.) was used as inert support and binder 
with the hematite to improve the oxygen carrier's reactivity and enhance its mechanical strength [79]. The Ca-enhanced hematite oxygen carrier was tested using an anthracite coal in a batch fluidized bed reactor. The calcium aluminate cement addition increased the coal gasification rate by a factor of two. This is mainly due to increasing the surface area of the oxygen carrier. The porous surface of the particle enhanced gas-solid reactions between the gasification products and the oxygen carrier. Additionally, calcium in the oxygen carrier promoted the WGS reaction (Reaction 22) in the forward direction. Furthermore, alkali metal salts catalyze steam gasification. Various coals may have different alkali metal content. A suitable selection of coal type or mixture could enhance the char gasification.

\subsection{Challenges and Recent Research on the CLOU Process}

For the solid fuel CLOU process, the oxygen carrier must have a suitable equilibrium partial pressure of oxygen at combustion temperatures $\left(800-1200^{\circ} \mathrm{C}\right)$ [43]. $\mathrm{Cu}, \mathrm{Mn}$, and Co-based oxygen carriers can release $\mathrm{O}_{2}$ at these temperatures and the equilibrium oxygen concentration increases with increasing temperature (Figure 8) [43]. The oxygen transport capacities $\left(R_{o c}\right)$ of $\mathrm{Cu}, \mathrm{Mn}$, and Co-based carriers are 10, 3.0, and 6.6 per $100 \mathrm{~g}$ of metal oxide respectively. Cobalt oxide has a low decomposition temperature, but there are concerns with the impact to health and the environment, so it is not considered as a suitable oxide [14]. Manganese oxide has re-oxidation issues of a slow rate at low operating temperatures and thermodynamic limitations at elevated temperatures [14]. As a result, it has not been investigated as much as copper oxide [74]. So far, unmodified $\mathrm{Mn}_{2} \mathrm{O}_{3}$ used in CLOU has not been successfully demonstrated. Compared to Mn-based materials, $\mathrm{Cu}$-based carriers have a faster rate of oxygen release [71], but the cost of $\mathrm{Cu}$ is greater than $\mathrm{Mn}$. Some Mn ores showed small CLOU behavior (oxygen release) [87].

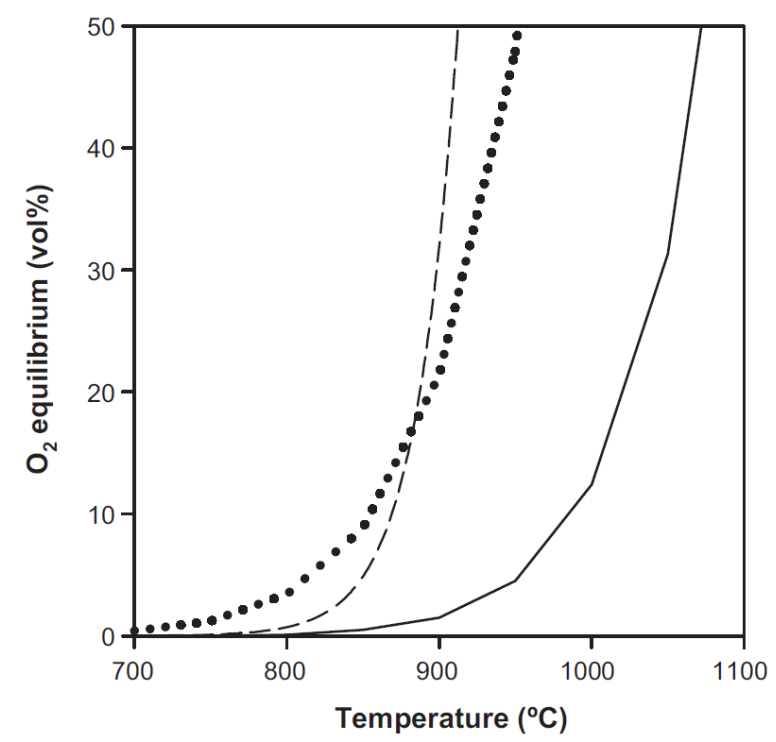

Figure 8. Equilibrium oxygen concentrations of $\mathrm{CuO} / \mathrm{Cu}_{2} \mathrm{O}(-), \mathrm{Mn}_{2} \mathrm{O}_{3} / \mathrm{Mn}_{3} \mathrm{O}_{4}(\bullet \bullet)$, and $\mathrm{Co}_{3} \mathrm{O}_{4} / \mathrm{CoO}(--)$ as a function of temperature [43].

A Cu-based carrier of $60 \% \mathrm{CuO}$ with $\mathrm{MgAl}_{2} \mathrm{O}_{4}$ as a support $(\mathrm{Cu} 60 \mathrm{MgAL})$ was tested in a $1.5 \mathrm{KW}$ continuously-operating CLOU reactor using bituminous coal (Table 2) [43] and milled pine wood chips [77]. This test demonstrated the proof of the concept CLOU process for coal combined with 
a Cu-based oxygen carrier. The major issue with $\mathrm{CuO}$ is the mechanical stability of the carrier during continuous operation [59]. The stability decreased substantially after $40 \mathrm{~h}$ of continuously operation [73]. Defluidization is a potential issue with $\mathrm{CuO}$. If it is operated for extended time in a fluidized bed it is over-reduced to $\mathrm{Cu}$, which has the low melting temperature of $1085^{\circ} \mathrm{C}$ [48]. Melting of $\mathrm{Cu}$ at high operating temperatures during CLOU may cause sintering and agglomeration of the oxygen carrier and result in the particle size changing. Complete reduction of $\mathrm{CuO}$ to $\mathrm{Cu}$ may happen in the reduction/oxidation cycles of $\mathrm{CuO} / \mathrm{Cu}_{2} \mathrm{O}$ with gaseous fuel $\mathrm{CH}_{4}$ and air at $950{ }^{\circ} \mathrm{C}$, especially when the methane concentration is high [14]. In addition, small amounts of char on the particle formed during the reduction step. Even if the deposited char is burned during the oxidation step, it may cause particle size changes and lower the $\mathrm{CO}_{2}$ capture efficiency. Researchers should pay attention to char deposition and agglomeration in addition to particle size changes.

Compared to the synthetic $\mathrm{Cu}$-based oxygen carrier, natural cupper ore is attractive for coal CLOU due to its low cost and rich reserves. Three natural cupper ores were investigated on cyclic oxygen release and uptake using a TGA and a fluidized bed [30]. TGA results showed that all three ores have high reactivity and cyclic stability. The cyclic study (20 cycles) of oxygen release $\left(980{ }^{\circ} \mathrm{C}\right.$ with $\left.\mathrm{CO}_{2}\right)$ and oxygen uptake $\left(800{ }^{\circ} \mathrm{C}\right.$ with air) were tested in the fluidized bed. All three ores showed the agglomeration tendency after different cycles. The agglomeration is dependent on the $\mathrm{Cu}$ content in the ore. The ore with low $\mathrm{Cu}$ content $(5.82 \mathrm{wt} \% \mathrm{CuO})$ did not agglomerate while the one with higher $\mathrm{Cu}$ content (63.25 wt \% and $87.28 \mathrm{wt} \% \mathrm{CuO}$ ) had serious agglomerations. Using a low $\mathrm{CuO}$ content ore in CLOU will require a very large solid recirculation rate and solid inventories which will result in some problems in the reactor design and operation. Natural copper ore with moderate $\mathrm{Cu}$ content $(44.39 \mathrm{wt} \%$ $\mathrm{CuO}$ ) in coal CLOU was studied from $900-950{ }^{\circ} \mathrm{C}$ in a batch fluidized bed [88]. The reaction rates of oxygen release and uptake increased with the temperature. Slight sintering and agglomeration of the ore were observed. Both of the fresh and used ore particles had $\mathrm{CuO}$ and $\mathrm{CuFe}_{2} \mathrm{O}_{4}$ as the main phase composition from XRD analysis. The specific surface area of used ore decreased to $0.115 \mathrm{~m}^{2} / \mathrm{g}$ from the fresh ore of $0.217 \mathrm{~m}^{2} / \mathrm{g}$. This may be due to the slight sintering of the ore particles and the blocking of pore by fly ash that generated from the coal combustion during the CLOU process. Future study is needed to increasing the $\mathrm{CuO}$ content in the natural cupper ore and at the same time to avoid its sintering and agglomeration problems.

To date, attention has focused on $\mathrm{Cu}$-based and $\mathrm{Mn}$-based materials mixed with $\mathrm{Ca}, \mathrm{Mg}, \mathrm{Cu}, \mathrm{Ni}, \mathrm{Fe}$ or Si $[47,48,57,58,89]$. Ryden et al. reviewed combined oxides for CLOU [48]. The secondary metal addition can enhance structural and/or thermodynamic properties compared to their parent oxides. The re-oxidation of manganese oxide is improved with the addition secondary metals such as $\mathrm{Fe}, \mathrm{Ni}$, $\mathrm{Mg}$, and $\mathrm{Ca}$ by raising the operation temperature $[49,90]$. However, the addition secondary metals tend to reduce the uncoupling capacity of Mn oxide [47,57,90]. Mixed Mn and Fe oxides are attractive based on their availability and low cost from minerals (ores) and industrial by-products. Recently the mixed oxides have been synthesized and tested mostly using gaseous fuels. As Mn content in the oxide increases up to $33 \%$ the oxygen uncoupling increase to $2 \%$ between 800 and $1100{ }^{\circ} \mathrm{C}$ [91]. To optimize the cost of the oxygen carrier in the CLOU process, a long life and/or a low cost of oxygen carrier are considered and still a challenge [92].

The carbon capture efficiency of the CLOU process is dependent on the fuel reactor temperature. From the $1.5 \mathrm{KW}$ coal CLOU test, the carbon capture efficiency was $97 \%$ at $900{ }^{\circ} \mathrm{C}$ and $99.3 \%$ at 
$960{ }^{\circ} \mathrm{C}$ [43]. This is due to the partial pressure of oxygen released from the $\mathrm{Cu}$-based oxygen carrier, which increases with increasing temperature (Figure 8) [43]. The outlet gas from the fuel reactor contains mainly $\mathrm{CO}_{2}, \mathrm{H}_{2} \mathrm{O}$, and $\mathrm{O}_{2}$ when the oxygen release rate of the carrier is high enough to supply an excess of gaseous oxygen. The gas and tar from pyrolysis are combusted by $\mathrm{O}_{2}$ (Figure 9). As a result, no oxygen polishing is needed. The char oxidation process is much slower than devolatilization because char oxidation is a heterogeneous reaction and devolatilization is a thermal decomposition reaction. Char oxidation rates vary with coal/biomass type, temperature, char characteristics (size, surface area, etc.), and oxidizer concentration [93]. On the other hand, char can also react with steam, $\mathrm{CO}_{2}$, and $\mathrm{H}_{2}$, but the rates of these reactions are considerably slower than with oxygen. In the $1.5 \mathrm{~kW}$ coal CLOU test, $\mathrm{N}_{2}$ or $\mathrm{CO}_{2}$ was used as a fluidizing gas. If the concentration of oxygen from the oxygen carrier is not high enough for char oxidization, char gasification needs to be considered along with the heterogeneous carbon oxidation [94]. Figure 10 shows the products of oxidation reactions as a function of oxygen to coal ratio, for gasification and combustion of Illinois \#6 coal [95]. Complete coal combustion takes place at a 2.5 oxygen to coal $(\mathrm{O} / \mathrm{C})$ ratio. As a result, excess oxygen carrier is needed to completely combust coal with a high oxygen release rate. Developing oxygen carriers for coal CLOU with a low cost and a sufficient reaction rate for thousands of cycles is needed.

When coal is combusted by $\mathrm{O}_{2}, \mathrm{SO}_{2}$ and $\mathrm{NO}_{x}$ may be generated due to the sulphur and nitrogen content in coal. Small amounts of $\mathrm{SO}_{2}$ and $\mathrm{NO}_{\mathrm{x}}$ were detected in the outlet gas stream from the fuel reactor in the $1.5 \mathrm{KW}$ coal CLOU test [43]. The release of $\mathrm{SO}_{2}$ and $\mathrm{NO}_{\mathrm{x}}$ into the air causes environmental problems. The sulfur contained in coal may reduce the oxygen carrier activity by poisoning the carrier. The effect of sulfur on the oxygen carrier requires further study [4].

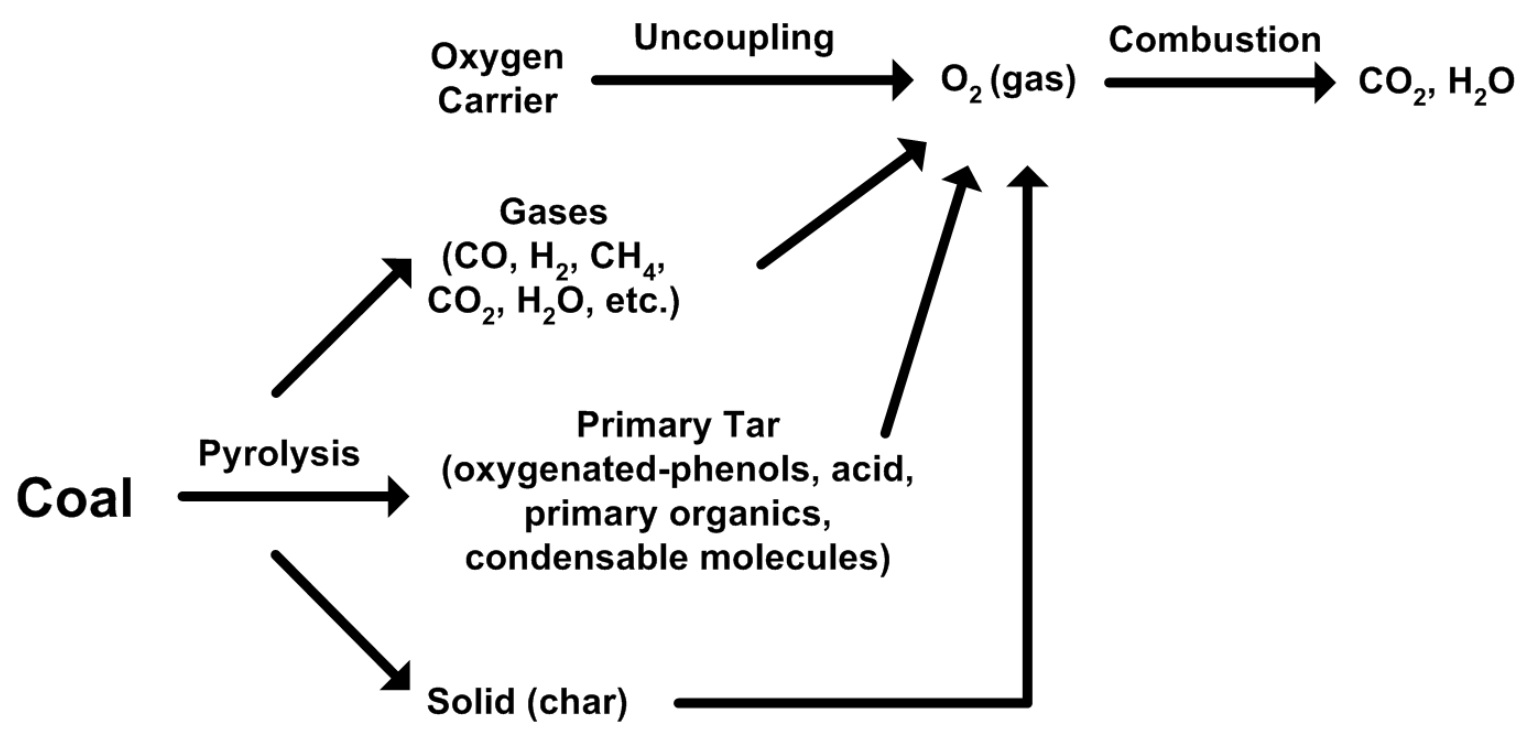

Figure 9. Coal reactions in the fuel reactor for CLOU. 


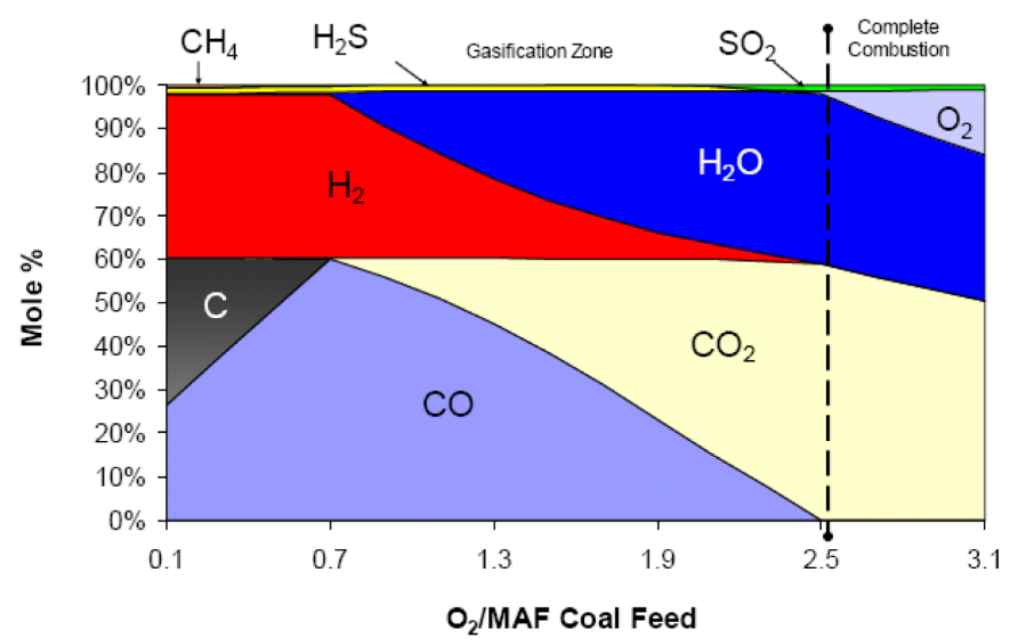

Figure 10. The products of oxidation reaction as a function of oxygen to coal ratio for gasification and combustion of Illinois \#6 coal with dry feeding [95].

\section{Concluding Remarks}

Chemical-looping technologies are some of the most promising $\mathrm{CO}_{2}$ capture technologies. Chemical-looping is a cyclical oxygen transporting process using oxygen carriers and consists of a fuel reactor, where the oxygen carrier reacts with fuel and an air reactor, where the reduced oxygen carriers are oxidized. Coal chemical-looping (solid-solid reaction) is more complicated than gaseous fuels (gas-solid reaction) due to complex coal properties. Coal is a heterogeneous material and consists of organic matter (carbon, hydrogen, oxygen, nitrogen and sulfur) and mineral matter (ash). The mineral matter/ash and sulfur may affect the activity of the oxygen carrier. Oxygen carriers are important in the development of chemical-looping processes. It is important to develop oxygen carriers using low cost materials which are adequate for different types of coal and chemical-looping processes. Thermogravimetric analysis (TGA) has been widely used for the development of oxygen carriers and to screen and characterize oxygen carriers at the lab scale. The reactivity and recyclability of oxygen carriers may be tested using TGA. In large scale fluidized bed studies, TGA can be used for a comparison of the oxygen carrier reactivity. Experimental results and kinetics of the oxygen carrier and solid fuel from TGA can provide useful information for the design and operation of chemical-looping processes.

Two proposed direct solid fuel chemical-looping combustion processes are in-situ Gasification Chemical-Looping Combustion (iG-CLC) and Chemical-Looping with Oxygen Uncoupling (CLOU). Based on pilot scale tests, high reactor temperatures will have high $\mathrm{CO}_{2}$ capture efficiency for both iG-CLC and CLOU. For large scale industrial applications of coal CLC, the availability of low cost oxygen carriers is very important. Low cost oxygen carriers with sufficient reactivity for coal CLC are preferred because of coal ash. For the coal iG-CLC process, natural minerals and industrial waste from steel and alumina production have been commonly tested in pilot scales. Enhancing the char gasification rate is a critical issue because char gasification is the rate limiting step in iG-CLC. $\mathrm{CO}_{2}$ and/or $\mathrm{H}_{2} \mathrm{O}$ as a gasifying agent are often used to improve the rate of char conversion. Research on enhancing char gasification under $\mathrm{H}_{2} \mathrm{O}$ and $\mathrm{CO}_{2}$ for different types of coal is needed. Alkali metal salts can catalyze the steam gasification. Various coals have different alkali metal content. A suitable selection of coal type or mixture could enhance char gasification. Volatiles in the fuel reactor, under a reducing environment, 
may not be completely converted. As a result, research is needed to investigate volatile reactions under chemical-looping conditions for coal with different volatile content. CLOU uses oxygen-carriers that can release gaseous oxygen at high temperature and overcome the low reactivity of char gasification. Volatiles can be completely combusted with excess oxygen released from the oxygen carrier. The coal CLOU process was tested at the pilot scale using a $\mathrm{Cu}$-based oxygen carrier. To fully convert the coal (volatiles and char), excess oxygen is needed. Developing oxygen carriers for solid fuel CLOU with low cost and sufficient reaction rate for thousands of cycles is needed. Additionally, the effect of $\mathrm{SO}_{2}$ and $\mathrm{NO}_{\mathrm{x}}$ generated from coal combustion requires further investigation.

\section{Acknowledgments}

This project was funded by the Department of Energy, National Energy Technology Laboratory, an agency of the United States Government, through a support contract with AECOM. Neither the United States Government nor any agency thereof, nor any of their employees, nor AECOM, nor any of their employees, makes any warranty, expressed or implied, or assumes any legal liability or responsibility for the accuracy, completeness, or usefulness of any information, apparatus, product, or process disclosed, or represents that its use would not infringe privately owned rights. Reference herein to any specific commercial product, process, or service by trade name, trademark, manufacturer, or otherwise, does not necessarily constitute or imply its endorsement, recommendation, or favoring by the United States Government or any agency thereof. The views and opinions of authors expressed herein do not necessarily state or reflect those of the United States Government or any agency thereof.

\section{Author Contributions}

Ping Wang is the primary author of this manuscript; the other authors participated in the discussion, development of the ideas and the implementation of the ideas, and to some extent in the writing and editing of the manuscript.

\section{Conflicts of Interest}

The authors declare no conflicts of interest.

\section{References}

1. World Energy Outlook 2014; International Energy Agency: Paris, France, 2014.

2. Velazquet-Vargas, L.G.; Devault, D.J.; Flynn, T.J.; Siengchum, T.; Zeng, L.; Tong, A.; Bayham, S.; Fan, L.S. Techno-economic analysis of a 550 MWe atmospheric iron-based coal-direct chemcial looping process. In Proceeding of 3rd International Conference on Chemical Looping, Goteborg, Sweden, 9-11 September 2014.

3. Adanez, J.; Abad, A.; Garcia-Labiano, F.; Gayan, P.; de Diego, L.F. Progress in chemical-looping combustion and reforming technologies. Prog. Energy Combust. Sci. 2012, 38, 215-282.

4. Fan, L.S. Chemical Looping Systems for Fossil Energy Conversions; John Wiley \& Sons, Inc.: Hoboken, NJ, USA, 2010; p. 420. 
5. Dieter, H.; Bidwe, A.R.; Varela-Duelli, G.; Charitos, A.; Hawthorne, C.; Scheffknecht, G. Development of the Calcium Looping $\mathrm{CO}_{2}$ Capture Technology from Lab to Pilot Scale at IFK, University of Stuttgart. Fuel 2014, 127, 23-37.

6. Cuadrat, A.; Abad, A.; Garcia-Labiano, F.; Gayan, P.; de Diego, L.F.; Adanez, J. Relevance of the coal rank on the performance of the in situ gasification chemical-looping combustion. Chem. Eng. J. 2012, 195, 91-102.

7. Saucedo, M.A.; Lim, J.Y.; Dennis, J.S.; Scott, S.A. $\mathrm{CO}_{2}$-gasification of a lignite coal in the presence of an iron-based oxygen carrier for chemical-looping combustion. Fuel 2014, 127, 186-201.

8. Hossain, M.M.; de lasa, H.I. Chemical-looping combustion (CLC) for inherent $\mathrm{CO}_{2}$ separations-A review. Chem. Eng. Sci. 2008, 63, 4433-4451.

9. Berguerand, N.; Lyngfelt, A. Design and operation of a $10 \mathrm{~kW}($ th) chemical-looping combustor for solid fuels-Testing with South African coal. Fuel 2008, 87, 2713-2726.

10. Cao, Y.; Pan, W.-P. Investigation of chemical looping combustion by solid fuels. 1. Process analysis. Energy Fuels 2006, 20, 1836-1844.

11. Leion, H.; Lyngfelt, A.; Johansson, M.; Jerndal, E.; Mattisson, T. The use of ilmenite as an oxygen carrier in chemical-looping combustion. Chem. Eng. Res. Des. 2008, 86, 1017-1026.

12. Leion, H.; Mattisson, T.; Lyngfelt, A. Solid fuels in chemical-looping combustion. Int. J. Greenh. Gas Control 2008, 2, 180-193.

13. Lyngfelt, A. Chemical-looping combustion of solid fuels - Status of development. Appl. Energy 2014, 113, 1869-1873.

14. Mattisson, T.; Lyngfelt, A.; Leion, H. Chemical-looping with oxygen uncoupling for combustion of solid fuels. Int. J. Greenh. Gas Control 2009, 3, 11-19.

15. Mendiara, T.; Abad, A.; de Diego, L.F.; Garcia-Labiano, F.; Gayan, P.; Adanez, J. Use of an Fe-based residue from alumina production as an oxygen carrier in chemical-looping combustion. Energy Fuels 2012, 26, 1420-1431.

16. Mendiara, T.; Garcia-Labiano, F.; Gayan, P.; Abad, A.; de Diego, L.F.; Adanez, J. Evaluation of the use of different coals in chemical looping combustion using a bauxite waste as oxygen carrier. Fuel 2013, 106, 814-826.

17. Acharya, B.; Dutta, A.; Basu, P. Chemical-looping gasification of biomass for hydrogen-enriched gas production with in-process carbon dioxide capture. Energy Fuels 2009, 23, 5077-5083.

18. Dennis, J.S.; Scott, S.A. In situ gasification of a lignite coal and $\mathrm{CO}_{2}$ separation using chemical looping with a Cu-based oxygen carrier. Fuel 2010, 89, 1623-1640.

19. Thunman, H.; Lind, F.; Breitholtz, C.; Berguerand, N.; Seemann, M. Using an oxygen-carrier as bed material for combustion of biomass in a 12-MWth circulating fluidized-bed boiler. Fuel 2013, 113, 300-309.

20. Leion, H.; Mattisson, T.; Lyngfelt, A. The use of petroleum coke as fuel in chemical-looping combustion. Fuel 2007, 86, 1947-1958.

21. Brown, T.A.; Dennis, J.S.; Scott, S.A.; Davidson, J.F.; Hayhurst, A.N. Gasification and chemical-looping combustion of a lignite char in a fluidized bed of iron oxide. Energy Fuels $\mathbf{2 0 1 0}$, 24, 3034-3048.

22. Lyon, R.K.; Cole, J.A. Unmixed combustion: An alternative to fire. Combust. Flame 2000, 121, 249-261. 
23. Miller, B.G. Coal Energy Systems; Elsevier: Burlington, MA, USA, 2005; p. 526.

24. Ward, C.R. Analysis and significance of mineral matter in coal seams. Int. J. Coal Geol. 2002, 50, 135-168.

25. Wang, P.; Massoudi, M. Slag behavior in gasifiers Part I: Influence of coal properties and gasification conditions. Energies 2013, 6, 784-806.

26. Gu, H.; Shen, L.; Xiao, J.; Zhang, S.; Song, T.; Chen, D. Evaluation of the effect of sulfur on iron-ore oxygen carrier in chemical-looping combustion. Ind. Eng. Chem. Res. 2013, 52, 1795-1805.

27. Arjmand, M.; Leion, H.; Lyngfelt, A.; Mattisson, T. Use of manganese ore in chemical-looping combustion (CLC)-Effect on steam gasification. Int. J. Greenh. Gas Control 2012, 8, 56-60.

28. Mendiara, T.; de Diego, L.F.; Garcia-Labiano, F.; Gayan, P.; Abad, A.; Adanez, J. Behaviour of a bauxite waste material as oxygen carrier in a $500 \mathrm{Wth}$ CLC unit with coal. Int. J. Greenh. Gas Control 2013, 17, 170-182.

29. Mendiara, T.; de Diego, L.F.; Garcia-Labiano, F.; Gayan, P.; Abad, A.; Adanez, J. On the use of a highly reactive iron ore in chemical looping combustion of different coals. Fuel 2014, 126, 239-249.

30. Wen, Y.-Y.; Li, Z.-S.; Xu, L.; Cai, N.-S. Experimental study of natural Cu ore particles as oxygen carriers in chemical looping with oxygen uncoupling (CLOU). Energy Fuels 2012, 26, 3919-3927.

31. Leion, H.; Mattisson, T.; Lyngfelt, A. Use of ores and industrial products as oxygen carriers in chemical-looping combustion. Energy Fuels 2009, 23, 2307-2315.

32. Moldenhauer, P.; Ryden, M.; Lyngfelt, A. Testing of minerals and industrial by-products as oxygen carriers for chemical-looping combustion in a circulating fluidized-bed $300 \mathrm{~W}$ laboratory reactor. Fuel 2012, 93, 351-363.

33. Berguerand, N.; Lyngfelt, A. Batch testing of solid fuels with ilmenite in a $10 \mathrm{~kW}(\mathrm{th})$ chemical-looping combustor. Fuel 2010, 89, 1749-1762.

34. Frohn, P.; Arjmand, M.; Azimi, G.; Leion, H.; Mattisson, T.; Lyngfelt, A. On the high-gasification rate of brazilian manganese ore in chemical-looping combustion (CLC) for solid fuels. Aiche J. 2013, 59, 4346-4354.

35. Xu, L.; Edland, R.; Li, Z.; Leion, H.; Zhao, D.; Cai, N. Cu-modified manganese ore as an oxygen carrier for chemical looping combustion. Energy \& Fuels 2014, 28, 7085-7092.

36. Bao, J.; Li, Z.; Cai, N. Reduction kinetics of foreign-ion-promoted ilmenite using carbon monoxide (CO) for chemical looping combustion. Ind. Eng. Chem. Res. 2013, 52, 10646-10655.

37. Song, T.; Shen, L.; Guo, W.; Chen, D.; Xiao, J. Enhanced reaction performance with hematite $/ \mathrm{Ca}_{2} \mathrm{Al}_{2} \mathrm{SiO}_{7}$ oxygen carrier in chemical looping combustion of coal. Ind. Eng. Chem. Res. 2013, 52, 9573-9585.

38. Gu, H.; Shen, L.; Xiao, J.; Zhang, S.; Song, T.; Chen, D. Iron ore as oxygen carrier improved with potassium for chemical looping combustion of anthracite coal. Combust. Flame 2012, 159, 2480-2490.

39. Cuadrat, A.; Abad, A.; Garcia-Labiano, F.; Gayan, P.; de Diego, L.F.; Adanez, J. Effect of operating conditions in chemical-looping combustion of coal in a $500 \mathrm{~W}$-th unit. Int. J. Greenh. Gas Control 2012, 6, 153-163.

40. Song, T.; Wu, J.; Zhang, H.; Shen, L. Characterization of an Australia hematite oxygen carrier in chemical looping combustion with coal. Int. J. Greenh. Gas Control 2012, 11, 326-336. 
41. Tong, A.; Bayham, S.; Kathe, M.V.; Zeng, L.; Luo, S.; Fan, L.-S. Iron-based syngas chemical looping process and coal-direct chemical looping process development at Ohio State University. Appl. Energy 2014, 113, 1836-1845.

42. de Diego, L.F.; Gayan, P.; Garcia-Labiano, F.; Celaya, J.; Abad, M.; Adanez, J. Impregnated $\mathrm{CuO} / \mathrm{Al}_{2} \mathrm{O}_{3}$ oxygen carriers for chemical-looping combustion: Avoiding fluidized bed agglomeration. Energy Fuels 2005, 19, 1850-1856.

43. Abad, A.; Adanez-Rubio, I.; Gayan, P.; Garcia-Labiano, F.; de Diego, L.F.; Adanez, J. Demonstration of chemical-looping with oxygen uncoupling (CLOU) process in a $1.5 \mathrm{~kW}(\mathrm{th})$ continuously operating unit using a Cu-based oxygen-carrier. Int. J. Greenh. Gas Control 2012, 6, 189-200.

44. Adanez-Rubio, I.; Gayan, P.; Garcia-Labiano, F.; de Diego, L.F.; Adanez, J.; Abad, A. Development of $\mathrm{CuO}$-based oxygen-carrier materials suitable for chemical-looping with oxygen uncoupling (CLOU) process. Int. Conference on Greenh. Gas Control Technol. 2011, 4, 417-424.

45. Gayan, P.; Adanez-Rubio, I.; Abad, A.; de Diego, L.F.; Garcia-Labiano, F.; Adanez, J. Development of $\mathrm{Cu}$-based oxygen carriers for chemical-looping with oxygen uncoupling (CLOU) process. Fuel 2012, 96, 226-238.

46. Adanez-Rubio, I.; Gayan, P.; Abad, A.; Garcia-Labiano, F.; de Diego, L.F.; Adanez, J. Kinetic analysis of a $\mathrm{Cu}$-based oxygen carrier: Relevance of temperature and oxygen partial pressure on reduction and oxidation reactions rates in chemical looping with oxygen uncoupling (CLOU). Chem. Eng. J. 2014, 256, 69-84.

47. Azimi, G.; Leion, H.; Ryden, M.; Mattisson, T.; Lyngfelt, A. Investigation of different Mn-Fe oxides as oxygen carrier for chemical-looping with oxygen uncoupling (CLOU). Energy Fuels 2013, 27, 367-377.

48. Ryden, M.; Leion, H.; Mattisson, T.; Lyngfelt, A. Combined oxides as oxygen-carrier material for chemical-looping with oxygen uncoupling. Applied Energy 2014, 113, 1924-1932.

49. Shulman, A.; Cleverstam, E.; Mattisson, T.; Lyngfelt, A. Manganese/iron, Manganese/nickel, and Manganese/silicon oxides used in chemical-looping with oxygen uncoupling (CLOU) for combustion of methane. Energy Fuels 2009, 23, 5269-5275.

50. Cuadrat, A.; Abad, A.; Garcia-Labiano, F.; Gayan, P.; de Diego, L.F.; Adanez, J. The use of ilmenite as oxygen-carrier in a $500 \mathrm{~W}$-th chemical-looping coal combustion unit. Int. J. Greenh. Gas Control 2011, 5, 1630-1642.

51. Markstrom, P.; Linderholm, C.; Lyngfelt, A. Chemical-looping combustion of solid fuels-Design and operation of a $100 \mathrm{~kW}$ unit with bituminous coal. Int. J. Greenh. Gas Control 2013, 15, 150-162.

52. Gu, H.; Shen, L.; Xiao, J.; Zhang, S.; Song, T. Chemical looping combustion of biomass/coal with natural iron ore as oxygen carrier in a continuous reactor. Energy Fuels 2011, 25, 446-455.

53. Cuadrat, A.; Linderholm, C.; Abad, A.; Lyngfelt, A.; Adanez, J. Influence of limestone addition in a $10 \mathrm{~kW}(\mathrm{th})$ chemical-looping combustion unit operated with petcoke. Energy Fuels 2011, 25, $4818-4828$.

54. Jin, H.G.; Ishida, M. A new type of coal gas fueled chemical-looping combustion. Fuel 2004, 83, 2411-2417.

55. Soncini, R.M.; Means, N.C.; Weiland, N.T. Co-pyrolysis of low rank coals and biomass: Product distributions. Fuel 2013, 112, 74-82. 
56. Weiland, N.T.; Means, N.C.; Morreale, B.D. Product distributions from isothermal co-pyrolysis of coal and biomass. Fuel 2012, 94, 563-570.

57. Azimi, G.; Leion, H.; Mattisson, T.; Ryden, M.; Snijkers, F.; Lyngfelt, A. Mn-Fe oxides with support of $\mathrm{MgAl}_{2} \mathrm{O}_{4}, \mathrm{CeO}_{2}, \mathrm{ZrO}_{2}$ and $\mathrm{Y}_{2} \mathrm{O}_{3}-\mathrm{ZrO}_{2}$ for chemical-looping combustion and chemical-looping with oxygen uncoupling. Int. J. Greenh. Gas Control 2014, 53, 10358-10365.

58. Pour, N.M.; Leion, H.; Ryden, M.; Mattisson, T. Combined $\mathrm{Cu} / \mathrm{Mn}$ oxides as an oxygen carrier in chemical looping with oxygen uncoupling (CLOU). Energy Fuels 2013, 27, 6031-6039.

59. Adanez-Rubio, I.; Arjmand, M.; Leion, H.; Gayan, P.; Abad, A.; Mattisson, T.; Lyngfelt, A. Investigation of combined supports for cu-based oxygen carriers for chemical-looping with oxygen uncoupling (CLOU). Energy Fuels 2013, 27, 3918-3927.

60. Shafiefarhood, A.; Stewart, A.; Li, F. Iron-containing mixed-oxide composites as oxygen carriers for chemical looping with oxygen uncoupling (CLOU). Fuel 2015, 139, 1-10.

61. Fan, L.; Li, F.; Ramkumar, S. Utilization of chemical looping strategy in coal gasification processes. Particuology 2008, 6, 131-142.

62. Mehdizadeh, A.M.; Klausner, J.F.; Barde, A.; Mei, R. Enhancement of thermochemical hydrogen production using an iron-silica magnetically stabilized porous structure. Int. J. Hydrog. Energy 2012, 37, 8954-8963.

63. United States Department of Energy/National Energy Technology Laboratory. Advanced Combustion Systems: Chemical Looping Summary; United States Department of Energy/National Energy Technology Laboratory: Pittsburgh, PA, USA, 2013.

64. de Diego, L.F.; Garcia-Labiano, F.; Adanez, J.; Gayan, P.; Abad, A.; Corbella, B.M.; Palacios, J.M. Development of $\mathrm{Cu}$-based oxygen carriers for chemical-looping combustion. Fuel 2004, 83, 1749-1757.

65. Anhenden, M. Chemical looping combustion: Emerging technology for $\mathrm{CO}_{2}$ capture. In Proceedings of the Clearwater Clean Coal Conference, Clearwater, FL, USA, 6-10 June 2010.

66. Linderholm, C.; Lyngfelt, A.; Cuadrat, A.; Jerndal, E. Chemical-looping combustion of solid fuels-Operation in a $10 \mathrm{~kW}$ unit with two fuels, above-bed and in-bed fuel feed and two oxygen carriers, manganese ore and ilmenite. Fuel 2012, 102, 808-822.

67. Leion, H.; Lyngfelt, A.; Mattisson, T. Solid fuels in chemical-looping combustion using a NiO-based oxygen carrier. Chem. Eng. Res. Des 2009, 87, 1543-1550.

68. Shen, L.; Wu, J.; Xiao, J. Experiments on chemical looping combustion of coal with a NiO based oxygen carrier. Combust. Flame 2009, 156, 721-728.

69. Shen, L.; Wu, J.; Gao, Z.; Xiao, J. Reactivity deterioration of $\mathrm{NiO} / \mathrm{Al}_{2} \mathrm{O}_{3}$ oxygen carrier for chemical looping combustion of coal in a $10 \mathrm{~kW}$ (th) reactor. Combust. Flame 2009, 156, 1377-1385.

70. Johansson, M.; Mattisson, T.; Lyngfelt, A. Investigation of $\mathrm{Mn}_{3} \mathrm{O}_{4}$ with stabilized $\mathrm{ZrO}_{2}$ for chemical-looping combustion. Chem. Eng. Res. Des. 2006, 84, 807-818.

71. Leion, H.; Larring, Y.; Bakken, E.; Bredesen, R.; Mattisson, T.; Lyngfelt, A. Use of $\mathrm{CaMn}_{0.875} \mathrm{Ti}_{0.125} \mathrm{O}_{3}$ as oxygen carrier in chemical-looping with oxygen uncoupling. Energy Fuels 2009, 23, 5276-5283.

72. Leion, H.; Mattisson, T.; Lyngfelt, A. Using chemical-looping with oxygen uncoupling (CLOU) for combustion of six different solid fuels. Energy Procedia 2009, 1, 447-453. 
73. Adanez-Rubio, I.; Gayan, P.; Abad, A.; de Diego, L.F.; Garcia-Labiano, F.; Adanez, J. Evaluation of a spray-dried $\mathrm{CuO} / \mathrm{MgAl}_{2} \mathrm{O}_{4}$ oxygen carrier for the chemical looping with oxygen uncoupling process. Energy Fuels 2012, 26, 3069-3081.

74. Zhao, H.; Liu, L.; Wang, B.; Xu, D.; Jiang, L.; Zheng, C. Sol-gel-derived NiO/NiAl $2 \mathrm{O}_{4}$ oxygen carriers for chemical-looping combustion by coal char. Energy Fuels 2008, 22, 898-905.

75. Siriwardane, R.; Tian, H.; Richards, G.; Simonyi, T.; Poston, J. Chemical-looping combustion of coal with metal oxide oxygen carriers. Energy Fuels 2009, 23, 3885-3892.

76. Cao, Y.; Casenas, B.; Pan, W.-P. Investigation of chemical looping combustion by solid fuels. 2. Redox reaction kinetics and product characterization with coal, biomass, and solid waste as solid fuels and $\mathrm{CuO}$ as an oxygen carrier. Energy Fuels 2006, 20, 1845-1854.

77. Adanez-Rubio, I.; Abad, A.; Gayan, P.; de Diego, L.F.; Garcia-Labiano, F.; Adanez, J. Biomass combustion with $\mathrm{CO}_{2}$ capture by chemical looping with oxygen uncoupling (CLOU). Fuel Process. Technol. 2014, 124, 104-114.

78. An, H.; Song, T.; Shen, L.; Zhang, L.; Feng, B. Hydrogen production from a victorian brown coal with in Situ $\mathrm{CO}_{2}$ capture in a $1 \mathrm{~kW}$ th dual fluidized-bed gasification reactor. Ind. Eng. Chem. Res. 2012, 51, 13046-13053.

79. Song, T.; Shen, L.; Zhang, S.; Chen, D.; Xiao, J. Performance of hematite $/ \mathrm{Ca}_{2} \mathrm{Al}_{2} \mathrm{SiO}_{7}$ oxygen carrier in chemical looping combustion of coal. Ind. Eng. Chem. Res. 2013, 52, 7350-7361.

80. Chuang, S.Y.; Dennis, J.S.; Hayhurst, A.N.; Scott, S.A. Development and performance of Cu-based oxygen carriers for chemical-looping combustion. Combust. Flame 2008, 154, 109-121.

81. Xiao, R.; Song, Q.; Song, M.; Lu, Z.; Zhang, S.; Shen, L. Pressurized chemical-looping combustion of coal with an iron ore-based oxygen carrier. Combust. Flame 2010, 157, 1140-1153.

82. Adanez, J.; Cuadrat, A.; Abad, A.; Gayan, P.; de Diego, L.F.; Garcia-Labiano, F. Ilmenite activation during consecutive redox cycles in chemical-looping combustion. Energy Fuels 2010, 24, 1402-1413.

83. Lee, S. Gasification of coal. In Handbook of Alternative Fuel Technologies; Sunggyu Lee, J.G.S., Loyalka, S.K., Eds.; CRC Press: New York, NY, USA, 2007.

84. Liu, Z.L.; Zhu, H.H. Steam gasification of coal char using alkali and alkaline-earth metal-catalysts. Fuel 1986, 65, 1334-1338.

85. Teyssie, G.; Leion, H.; Schwebel, G.L.; Lyngfelt, A.; Mattisson, T. Influence of lime addition to ilmenite in chemical-looping combustion (CLC) with solid fuels. Energy Fuels 2011, 25, 3843-3853.

86. Yu, Z.; Li, C.; Jing, X.; Wang, Z.; Fang, Y.; Huang, J. Catalytic chemical looping combustion of carbon with an iron-based oxygen carrier modified by $\mathrm{K}_{2} \mathrm{O}_{3}$ : Catlytic mechanism and multicycle tests. Fuel Process. Technol. 2015, 135, 119-124.

87. Arjmand, M.; Leion, H.; Mattisson, T.; Lyngfelt, A. Investigation of different manganese ores as oxygen carriers in chemical-looping combustion (CLC) for solid fuels. Appl. Energy 2014, 113, 1883-1894.

88. Zhao, H.; Wang, K.; Fang, Y.; Ma, J.; Mei, D.; Zheng, C. Characterization of natural copper ore as oxygen carrier in chemical-looping with oxygen uncoupling of anthracite. Int. J. Greenh. Gas Control 2014, 22, 154-164.

89. Arjmand, M.; Frick, V.; Ryden, M.; Leion, H.; Mattisson, T.; Lyngfelt, A. Screening of combined Mn-Fe-Si oxygen carriers for chemical looping with oxygen uncoupling (CLOU). Energy Fuels 2015, 29, 1868-1880. 
90. Shulman, A.; Cleverstam, E.; Mattisson, T.; Lyngfelt, A. Chemical-Looping with oxygen uncoupling using $\mathrm{Mn} / \mathrm{Mg}$-based oxygen carriers-Oxygen release and reactivity with methane. Fuel 2011, 90, 941-950.

91. Larring, Y.; Braley, C.; Pishahang, M.; Andreassen, K.A.; Bredesen, R. Evaluation of a mixed Fe-Mn oxide system for chemical looping combustion. Energy Fuels 2015, 29, 3438-3445.

92. Abad, A.; García-Labiano, F.; de Diego, L.F.; Gayán, P.; Adánez, J. $\mathrm{CO}_{2}$ capture activities in ICB-CSIC: Chemical-looping combustion and oxy-fuel. In Proceedings of the 63rd IEA Fluidized Bed Conversion Meeting, Ponferrada, Spain, 29-30 November 2011.

93. Smoot, D.L.; Smith, P.J. Coal Combustion and Gasification; Plenum Publishing Corporation: New York, NY, USA, 1985; p. 444.

94. Wang, P.; Means, N.; Shekhawat, D.; Berry, D. The reactivity of coal char in chemical looping gasification and combustion. In Proceedings of the World of Coal Ash, Nashville, TN, USA, 5-7 May 2015.

95. Wang, P.; Massoudi, M. Effect of Coal Properties and Operation Conditions on Flow Behavior of Coal Slag in Entrained Flow Gasifier: A Brief Review; United States Department of Energy National Energy Technology Laboratory: Pittsburgh, PA, USA, 2011.

(C) 2015 by the authors; licensee MDPI, Basel, Switzerland. This article is an open access article distributed under the terms and conditions of the Creative Commons Attribution license (http://creativecommons.org/licenses/by/4.0/). 